\title{
Okul Öncesi Eğitim Programı İle İlgili Dergipark'ta Yayımlanan Makalelerin İncelenmesi: 2013-20201
}

DOI: $10.26466 /$ opus.866620

\author{
* \\ Nazlı Sila Yerliyurt* - Mustafa Ersoy ** \\ * Yüksek Lisans Öğrencisi, Sivas Cumhuriyet Üniversitesi, Eğitim Fakültesi, Sivas/Türkiye \\ E-Posta: nazli_sila@hotmail.com ORCID: 0000-0002-6926-8000 \\ ** Dr. Öğretim Üyesi, Sivas Cumhuriyet Üniversitesi, Eğitim Fakültesi, Sivas/Türkiye \\ E-Posta: mstfrsy@gmail.com \\ ORCID: 0000-0002-7320-8844
}

\begin{abstract}
Öz
Bu araştırmada, nitelikli bir okul öncesi eğitim programının çocuğun bütün hayatı üzerinde etkili olması nedeniyle daha detaylı incelenmesi ve yaşadığg sorunların saptanarak bu sorunların çözümü için faydah olacak saptamalar yapılması, alan yazında eksik görülen konuların belirlenerek ilerleyen yıllarda araştırmacılara ışık tutması amaçlanmıştır. Araştırmanın çalışma grubunu amaçsal örneklemenin bir çeşidi olan ölçüt örnekleme yöntemine göre seçilmiş, 2013 yılından sonra yapılan program güncellemesi dikkate alınarak 7 yılda (2013-2020) yayımlanan okul öncesi eğitim programı içerikli 201 adet makale oluşturmuştur. Araştırma kapsamında veriler Dergipark veritabanında yer alan 2013-2020 yılları arasında yazılmış okul öncesi eğitim programı hakkındaki makalelerin alanyazın taraması yapılarak toplanmış, uzman görüşleri alınarak kuramsallaştırılmış ve her makaleye birden başlayarak sayılar verilmiştir. Toplanan veriler MAXQDA programı ile analiz edilmiş, kategoriler ve kodlar oluşturulmuştur. Araştırma sonucunda okul öncesi eğitime dış faktörlerin oldukça büyük etkisi olduğu, programın çocukların gelişim özelliklerini dikkate alarak ve diğer derslerin eğitim

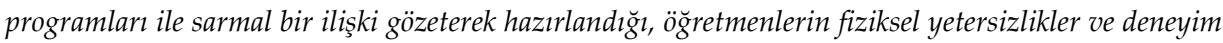
eksikliği nedeniyle uygulama aşamasında sorunlar yaşayabildiği ortaya çıkmıştır. Okul öncesi eğitim programı uygulanırken öğretmenlere hizmet içi eğitimler düzenlenmesine önem verilmesi, aile eğitimleri konusunda daha fazla çalışma yapılması ve çocuklarm araştırıcılık özelliğini geliştirmek üzerine yapılacak çalışmaların artırılması önerilmiştir.
\end{abstract}

Anahtar Kelimeler: Okul Öncesi Ĕ̆itim, Okul Öncesi Ĕ̆itim Programı, İçerik Analizi, $M A X Q D A$ Programı

\footnotetext{
1 "Okul Öncesi Eğitim Programı ile Ilgili Dergipark'ta Yayımlanan Makalelerin Incelenmesi: 2013-2020" adlı çalışmamıza "Bu çalışma birinci yazar olarak ismi geçen Nazlı Sıla YERLIYURT'Un Mustafa ERSOY danışmanlığında tamamladığı yüksek lisans tezinden uyarlanarak gerçekleşmiştir.
} 


\title{
An Examination of Articles Published in Dergipark Regarding Preschool Education Program
}

\begin{abstract}
This study aimed to examine a qualified preschool education program in more detail, to reveal the problems experienced by the child and to make useful determinations for the solutions of them and to shed light on the researchers in the following years by contributing to the literature. The study group of the study, selected according to the criterion sampling method, consisted of 201 articles on preschool education program published in the last 7 years (2013-2020) within the scope of the program updated in 2013. The data were collected by scanning the relevant articles published between 2013-2020 in the Dergipark database. Categories and codes were created with the content analysis through MAXQDA program. The results revealed that non-school factors had a great influence on preschool education, the program was prepared by considering the developmental characteristics of the children and a spiral relationship with educational programs of other courses, and teachers may have problems during the implementation phase due to physical inadequacies and lack of experience. While implementing the pre-school education program, it was suggested that in-service training programs for teachers should be organized, more studies on family education and developing the research skills of children. should be carried out.
\end{abstract}

Keywords: Preschool Education, Preschool Education Program, Content Analysis, MAXQDA program 


\section{Giriş}

Eğitim, insanoğlu öğrenmeye başladığı andan itibaren ortaya çıkar ve kişinin yaşamı boyunca devam ederek kalıcı öğrenmeler sağlar (Aydın, 2006). Bütün bu kalıc öğrenmelere yol açması ile eğitim, yüksek bir yaşam düzeyine ulaşmanın ve toplum olarak daha ileri düzeye gitmemizin kaynağ olarak görülmektedir (Livatyall, 2011). Tüm bu sebeplerle bütün ülkeler her geçen gün eğitime daha çok önem vermekte ve kaynakların daha fazla ayırmaktadırlar (Kale, 2010). 1959 yılında kabul edilen Birleşmiş Milletler Çocuk Hakları Sözleşmesi çocuğun haklarını eşitlik temeli doğrultusunda koruyarak çocuklara toplumun yararlı bir üyesi olmayı sağlayacak eğitimi vermektedir. Çocuk, dünyanın neresinde doğduğuna bakılmaksızın sağlıklı bir şekilde yetişme hakkına sahiptir ve bu nedenle okul öncesi eğitim bütün eğitim sistemi içinde riske atılamayacak kadar önemli bir basamak olarak görülmektedir (Yılmaz, 2003).

Okul öncesi dönem, yaşamın ve eğitimin temelidir (Alisinanoğlu ve Kesicioğlu, 2010). Bu dönem çocukların hızla büyüyüp geliştiği bir dönemdir ve gelişim alanlarında yeterli duruma büyük bir hızla gelirler (MEB, 2013). Okul öncesi eğitim, çocuğun doğumundan ilkokula başlayacağı güne kadar olan yılları kapsayan ve çocukların bütün hayatı boyunca önemli etkisi olan, bedensel, motor, sosyal duygusal, zihinsel ve dil gelişimlerinin büyük bir kısmının tamamlanarak kişiliklerinin şekil aldığı, hem ailede hem de kurumlarda verilebilen eğitim sürecidir (Aral, Baran, Bulut ve Çimen, 2002). Bloom'un araştırma sonuçlarında çocukların yaşamlarının ilk 4 yılında zihinsel gelişimlerinin \%50'sinin tamamlandığı görülmektedir. Aynı araştırmada çocukların geriye kalan gelişimlerinin \%30'unun dört-sekiz yaşları arasında, \%20'sinin ise sekiz-on yedi yaşları arasında tamamlandığından söz edilmektedir (Bloom, 1956; akt: Fidan ve Erden, 1993). Bu sebeplerden dolayı bu gelişim dönemlerinde alınan okul öncesi eğitim büyük bir önem taşımaktadır (Ekici, 2014; Pehlivan, 2006; Uyanık ve Kandır, 2010).

Türkiye'de özel okullarda ve kamu kurumlarında karma olarak yürütülen okul öncesi eğitime maliyetinin yüksek olması ve diğer kademelerde de gözlenebilir özelliklerinin olduğunun düşünülmesi nedeniyle yeterli kaynak ayırılmadığı için okul öncesi eğitim ailelerin ve yerel yönetimlerin sorumluluğuna bırakılmıştır (Oktay, 1999; Saklan ve Erginer, 2016). Son yıllarda ise okul öncesi eğitimin önemi giderek artmakta ve Milli Eğitim Bakanlığı bün- 
yesindeki bağımsız anaokulları, ilkokul, ortaokul ve liseler kapsamında açılan anasınıfları, kız meslek liselerine bağlı uygulama anaokulları ve anasınıfları ile Sosyal Hizmetler Çocuk Esirgeme Kurumu, üniversiteler, Çalışma Bakanlığı ve çeşitli vakıf, derneklere bağlı olarak açılan okul öncesi eğitim kurumları gibi yerlerde eğitim devam etmektedir (Oktay, 2000). Okullaşma çabaları devam etmekte olup okul öncesi eğitim kapsamında 31.813 kurum, 1.564.813 öğrenci, 93.302 öğretmen ve 81.297 derslik bulunmaktadır (MEB Strateji Geliştirme Başkanlığı, 2018).

Okul öncesi eğitimin sistemli bir şekilde yürütülebilmesi için okul öncesi eğitim programının gerekliliği önemli bir unsurdur (Bertrand, 2012). Bu anlamda çocuğun gelişim alanların destekleyecek ve süreci düzgün yürütmeye yardımcı olacak şekilde okul öncesi eğitim programı hazırlanmalıdır (MEB, 2013). Okul öncesi eğitim programları çocuğun ilk öğrenme deneyimlerini oluşturmaktadır (Bertrand, 2012). Program yenilikçi, yaratıcı, problem çözme yeteneğine sahip, olayları değerlendirebilen, kendi kültürünün ve diğer kültürlerin değer yargıların yorumlayabilen ve bütün iyi özelliklerini insanlık için kullanabilen bireyler oluşturmayı amaçlar (Tuğrul, 2006). Türkiye'de okul öncesi eğitim programlarının güncellenme tarihleri 1952, 1989, 1994, 2002, 2006 ve 2013 olarak sıralanmaktadır. Yeni okul öncesi eğitim programı 2006 yılında uygulamaya konulmuştur fakat 2013 yılında tekrar gözden geçirilmiştir (MEB, 2013).

2013 yılı okul öncesi eğitim programında amaç ve kazanım ifadeleri yerine kazanım ve gösterge ifadeleri gelmiştir. Sınıfta bulunan ilgi köşeleri öğrenme merkezi olarak değiştirilmiş ve bu merkezlerin dolap, halı gibi ürünler kullanılarak birbirlerinden ayrılması önerilmiştir. Rehberlik ve özel eğitim hizmetlerine diğer programlara göre daha fazla önem verilerek hazırlanmıştır (Çalışandemir, 2014). Okul Öncesi Eğitim Programı ile çocuğun yeni karşılaştığı olaylar karşısında nasıl davranması gerektiği ve yeni tanıdığ1 kişilerle nasıl doğru iletişim kurması gerektiği, yaşadığı toplum ile uyum için yaşaması için ne yapması gerektiği sunulmuştur (MEB, 2013; Özsırkıntı, Akay ve Yılmaz-Bolat, 2014). Ülkemizde bu zamana kadar uygulanan okul öncesi eğitim programlarının özelliklerine bakıldığı zaman esnek, öğrenciyi merkezde tutan ve çocukların gelişim alanlarını destekleyici olarak hazırlandığı ve alınan dönütler sonucunda ihtiyaçlarının daha iyi karşılanması için güncellendiği söylenebilir (Düşek ve Dönmez, 2012). Bu güncellemeler doğrultusunda Türkiye'de yapılan çalışmalara bakıldığı za- 
man da (Örneğin: Dağll, 2007; Erbay, 2008; Taner ve Başal, 2005; Erkan ve Kırca, 2010; Uysal ve Balkan, 2015) okul öncesi eğitimi alan çocuklar ile almayan çocuklar arasında ilköğretimin ilk yıllarında gelişim alanlarında farklılıklar olduğu görülmektedir (Tantekin Erden ve Altun, 2014). Okul öncesi eğitim programı, öncelikle temel yaşam becerilerini öğreten ve çocuğu fizyolojik, zihinsel, çevresel, duygusal faktörler açısından ilkokula hazırlamayı kendine öncelik edinen bir programdır (Güldalı ve Demirbaş, 2017). Okul Öncesi Eğitim Programı, ilerlemecilik felsefesini benimseyen, farklı eğitim yaklaşımlarını yansıtan eklektik ve sarmal bir programdır (Gürkan ve Koran, 2014). Türkiye'de okul öncesi eğitimde sadece MEB Talim Terbiye Kurulu'nun onayladığı Okul Öncesi Eğitim Programı uygulanmamaktadır. Bunların yanı sıra özellikle kreşlerde ve özel anaokullarında PYP, Montessori, High Scope ve Reggio Emilio gibi okul öncesi ile ilişkili farklı eğitim modelleri de uygulanmaktadır (Yiğit, Özyurt ve Adıyaman, 2019). Okul öncesi eğitim programının nitelikli olması için çocukların bütün gelişim alanların desteklemesi gerekmektedir (Morrison, 2012; Zembat, 2007). Bütün gelişim alanlarının desteklenmesi doğrultusunda hazırlanan programda çocuklara beceri kazandırmak için gelişim alanlarını destekleyecek etkinlikler yer almalıdır (MEB, 2013). Okul öncesi eğitim programında Fen, Türkçe, Matematik, Okuma-Yazmaya Hazırlık, Müzik, Alan Gezileri, Hareket, Oyun, Drama ve Sanat etkinlikleri yer almaktadır (MEB, 2013). Program çocukların oyun yoluyla keşfederek öğrenmesini temel alır. Çok yönlü değerlendirme yapan programda özel eğitim gereksinimi olan çocuklara uyarlamalar yapılmaktadır. Çocuğun çok yönlü desteklenmesine yardımcı olan programı diğer okul öncesi programlarından ayıran fark rehber öğretmenler ile daha çok iletişim kurması ve aile katılımına öncelikli olarak yer vermesidir (MEB, 2013).

İlgili literatür incelendiğinde şu araştırmalara rastlanmaktadır. Kök, Koçyiğit, Tuğluk ve Bay (2008), okul öncesi eğitimin çocukların psikolojik problemlerinin tespitinde çok önemli bir rolü olduğunu ve okul öncesi öğretmenlerinin iyi gözlem yaptıkları takdirde sorunları erkenden tespit edebileceklerini vurgulamışlardır. Aslanargun ve Tapan (2011), okul öncesi eğitim alan çocukların kendilerini ifade etme becerilerinin geliştiğini, sosyalleştiklerini, akranları ve öğretmenleriyle daha kolay iletişime geçtiklerini vurgulamışlardır. Düş̧ek ve Dönmez (2012), okul öncesi eğitim programlarının gerekliliğine değinmiş ve geçmişten bugüne ülkemizde uygulanmış ve 
halen uygulanmakta olan okul öncesi eğitim programların inceleyerek özellikleri hakkında bilgi vermişlerdir. Sapsağlam (2013), ülkemizde kullanılan okul öncesi eğitim programlarının değerlendirme süreçlerini incelemiş ve ülkemizde uygulanan ve hala uygulanmakta olan programlar hakkında bilgi vermişlerdir. Özsırkıntı, Akay ve Yılmaz Bolat (2014), öğretmenlerin programı öğrenci merkezli ve aktif öğrenmeye olanak sağladığı yönünde değerlendirdiklerini, kazanım göstergelerin açk ve anlaşlır olduğunu düşündüklerini, fiziksel imkansızlıkların uygulama aşamasında zorluk çıarttığını söylediklerini ve hizmet içi eğitimlere olumlu baktıklarını dile getirmişlerdir. Coşkun ve Baş (2015), velilerin çocuk yetiştirirken daha çok kendi anne babalarından gördükleri yöntemleri uyguladıklarına ve anneler ile babaların görüşleri arasında belli bir farklılık olmadığı sonucuna da değinmişlerdir. Gürkan ve Koran (2015), okul öncesi eğitim programının dolaylı yollardan da olsa çocukların katılım hakkına yer verdiğini, aykırı bir durum gözlenmediğini ifade etmişlerdir. Kartal ve Güner (2016), okul öncesi eğitim programında dil gelişimi alanı içinde yer alan ses bilgisi farkındalığı ile ilgili kazanımları içeren etkinlikleri inceleyerek, yeterli sayıda etkinlik bulunmadığını ve etkinliklerin geliştirilmesi gerektiğini belirtmişlerdir. Gülay Ögelman ve Karakuzu (2016), sınıfların çoğunluğunda sanat ve geçici ilgi merkezi olmadığı, yazı ve resim çalışmalarının beklenilen düzeyden daha aşağıda olduğu, merkezlerin birbirinden düzgün ayrılmadığını belirtmişlerdir. Koç Akran ve Kocaman (2018), öğretmenlerin veli toplantılarını belli bir plan doğrultusunda gerçekleştirdiğini ve kadın velilerin toplantılara daha çok katılım sağlayarak çocukların durumları hakkında daha çok soru sorduklarını belirtmişlerdir. Bildiren (2018), okul öncesi dönemdeki çocukların bilişsel yetenekleri ve problem çözme becerileri arasında anlamlı bir ilişki olduğunu belirtmiştir. Bartan ve Başal (2018), öğretmenlerin bilimsel süreç becerileri hakkında orta düzeyde bilgi sahibi olduklarını ve sınıf içi uygulamalarda yetersiz kaldıklarını ifade etmişlerdir. Deniz ve Yıldız (2018), cinsel eğitim ile ilgili eksik bulunan kazanımların tespit edilerek programa dahil edilmesi gerektiği vurgulanmıştır. Erşan (2019), eğitim düzeyi yüksek ailelerin yabancı dil ve sosyal aktivite konusunda daha hassas olduklarından ve velilerin öğretmenden çocuklarına karşı olumlu tutum sergilemesini beklediklerinden söz etmiştir. Güzelyurt, Birge ve Ökten (2019), okul öncesi öğretmenlerinin ailelerle iletişim kurarken sorun yaşaması ve deneyim eksikliği yaşamaları sebebiyle aile eğitimini önemsemediklerini ve aile eğitimi 
uygulamalarında yetersiz oldukların ifade etmişlerdir. Ayyıldız ve Kahraman (2019), öğretmenlerin sınıfların fiziksel durumundan şikayetçi olduklarını ve iyileştirmeler yapılması gerektiğini vurgulamışlardır. Kutlu Abu ve Kayar (2020), ailelerin aile katılımı konusunda yeterince bilgi sahibi olmad1ğı, okul dışı etkinliklerin daha çok planlanmasına özen gösterilmesi ve etkinliklerin uygulanması için öğretmenlere ve ebeveynlere nitelikli eğitimlerin düzenlenmesi gerektiğini ifade etmişlerdir. Yalçın, Durmuşoğlu Saltalı ve Ateş (2020), okul öncesi öğretmenlerinin çocuğuyla kaliteli zaman geçiren, okulda öğrenilenleri evde tekrar eden ve saygıya dayalı iletişim kuran velileri daha çok istediklerini vurgulamışlardır. Muşlu Kaygısız (2020), okul öncesi eğitim programında yer alan kazanımların çevre eğitimi açısından yetersiz olduğunu ve çevre problemlerinin çözümüne yönelik önerilerde fen bilimleri dersi ile ortak hedefler içinde bulunduğunu vurgulamıştır. Özenç (2020), okul öncesi eğitim programının dil, motor ve öz bakım becerileri anlamında ilkokul programı ile uyumlu olduğunu fakat sosyal duygusal ve bilişsel gelişim alanlarında uyumsuzluklar olduğunu ifade etmiştir. Sapsağlam (2020), okul öncesi eğitim programlarının milli kavramlar açsından incelenmesi adlı çalışmasında okul öncesi eğitim programında milli kavramlara yeterli düzeyde yer verilmediğini vurgulamıştır.

Bu çalışmada, nitelikli bir okul öncesi eğitim programının çocuğun bütün hayatı üzerinde etkili olması nedeniyle daha detaylı incelenmesi ve yaşadığı sorunların saptanarak bu sorunların çözümü için faydalı olacak saptamalar yapılması, alan yazında eksik görülen konuların belirlenerek ilerleyen yıllarda araştırmacılara ışık tutması amaçlanmaktadır.

\section{Alt Amaçlar}

1. Okul Öncesi Eğitim Programına etki eden okul dışı faktörler nelerdir?

2. Okul Öncesi Eğitim Programlarının özellikleri nelerdir?

3. Okul Öncesi Eğitim Programının içerdiği ölçütlere ulaşma ve ulaşamama sebepleri nelerdir?

4. Okul Öncesi Eğitim Programlanı uygulanırken yaşanan sorunlar nelerdir? 


\section{Yöntem}

$\mathrm{Bu}$ araştırmada 2013-2020 yılları arasında okul öncesi eğitim programı alanında yazılan makaleleri incelemek amacıyla nitel araştırma yöntemlerinden içerik analizi yöntemi kullanılmıştır. İçerik analizi yöntemi meta analiz, meta sentez ve betimsel içerik olmak üzere üç başlıktan oluşmaktadır (Çalık ve Sözbilir, 2014). Bu çalışmada betimsel analiz yönteminden yararlanılmıştir.

Nitel araştırma yönteminde nitel veriler üzerinde yapılan veri analizleri kullanılmaktadır (Sönmez ve Alacapınar, 2011). Nitel araştırma desenlerinde tümevarımsal bir yol izlenmekte-dir. Disiplinlerarası bütüncül bir bakış açısı kullanarak araştırma problemini yorumlayan nitel araştırmalarda, araştırma yapılan olgu ve olaylar kendi bağlamında ele alınır ve insanlar onlara anlamlar yükleyerek yorumlarlar (Altunışık ve Diğerleri, 2010). Nitel araştırma, sosyal yaşam ve insanların problemlerinin özgün metodlarla sorgulandığı ve anlamlandırıldığı bir süreçtir (Creswell, 1998). Araştırma esnasinda veriler teker teker okunduktan sonra kodlama yapılır ve kategorize edilir. Bu kodlar ve kategoriler ışığında araştırma sonuçları ortaya koyulur (Merriam, 1998).

Bu araştırmada kullanılan içerik analizi özellikle sosyal bilimler alanında kullanılan ve insan davranışları üzerinde doğrudan olmayan davranışlarla çalışmaya imkân tanıyan bir tekniktir. İçerik analizi, metnin bazı kısımları kodlamalarla daha küçük içerik kategorilerine ayrılarak sistematik bir şekilde özetlenir (Büyüköztürk vd., 2008). Metinlerin düzenlenmesi, sinffland1rılması, karşılaştırılması ve metinlerden teorik sonuçlar çıkarılmasından oluşan bir araştırma tekniğidir (Cohen, Manion ve Morrison, 2007). İçerik analizi her türlü yazılı, sözlü materyal için objektif bir değerlendirme yapılabilmesini sağlar (Tavşancıl ve Aslan, 2001).

\section{Çalışma Grubu}

Araştırmanın çalışma grubunu amaçsal örneklemenin bir çeşidi olan ölçüt örnekleme yöntemine göre ve okul öncesi eğitim programının son güncellenme tarihi ile günümüz dikkate alınarak seçilen 2013-2020 yılları arasında okul öncesi eğitim programı alanında yazılmış olan ve Dergipark'ta yayımlanmış olan 201 adet makale oluşturmuştur. Ölçüt örneklem, araştırmada 
belli bir dizi ölçütü ya da araştırmacı tarafından belirlenen belli bir ölçütün kullanılması ile olan araştırma yöntemidir (Yıldırım ve Şimşek, 2006). Çalışmada birinci ölçüt olarak makalelerin Dergipark'ta yayımlanmış olması, ikinci ölçüt olarak 2013-2020 yılları arasında yayımlanmış olması, üçüncü ölçüt olarak "okul öncesi eğitim programı", "okul öncesi eğitim", "okul öncesi eğitimde nitelik", "eğitim programları" anahtar kelimelerin yer alması kullanılmıştır. Araştırmada sadece okul öncesi eğitim programı hakkında yanıt aradığımız sorulara cevap verebilecek içeriğe sahip makaleler kullanılmıştır.

\section{Veri Toplama Aracı}

Araştırma kapsamında Dergipark sitesinde yer alan 2013-2020 yılları arasında yazılmış okul öncesi eğitim programı hakkındaki makalelerin araması yapılmıştır. İlgili literatür taraması uzman görüşleri yardımıyla değerlendirilerek kuramsal boyut oluşturulmuştur. Makaleler pdf formatında bilgisayar ortamına aktarılmış ve her aktarılan makaleye birden başlayarak bir sayı verilmiştir. Araştırmaların konusu belirlenirken 201 makalenin özet ve tam metinleri incelenmiştir. Çalışmanın içerik analizinin uygulanması dört aşamada gerçekleştirilmiştir:

1. Verilerin kodlanması,

2. Temaların bulunması,

3. Kodların ve temaların düzenlenmesi,

4. Bulguların tanımlanması ve yorumlanması.

Çalışmada kodlama yapılmadan önce çalışmanın geçerliliği ve güvenirliliği çalışmaları yapılmıştır. Veri toplama aracının içerik geçerliği, alan eğitiminde uzman iki Doç. Dr., bir Dr. Öğr. Üyesi incelemesi doğrultusunda incelenerek çalışmanın amacına uygun olduğuna karar verilmiştir.

\section{Araştırmanın Geçerlik Güvenirliği}

Nitel araştırmalarda geçerlik güvenirlik koşullarının sağlanması gerekmektedir. Araştırmacılara çalışma süresince esnek yaklaşım sağlanması verileri kişisel deneyimler doğrultusunda yorumlanmasına açık hale getirmektedir. $\mathrm{Bu}$ nedenle araştırmaların daha kaliteli ve kapsamlı olması amaçlanarak çalışmaya katkı sağlayan özelliklerin planlı ve kontrollü kullanılması önem arz etmektedir. Açık, anlaşılır ve net bir biçimde açılamaları gerekli kılan 
araştırma süreci bu nedenle güvenirlik ve geçerlik koşullarına uyarak gerçekleştirilmelidir (Batdı, 2019).

Güvenirliğin alt kavramları inanırlık, aktarılabilirlik, güvenilebilirlik ve kanıtlanabilirliktir. Çalışmalara katılan katılımcıların buldukları verilerin gerçeklikle örtüşme durumlarına inanırlık denmektedir. Bu çalışmada araştırmaya dahil edilen araştırmalarda yer alan direkt alıntılara yer verilmesi ile inanırlığın sağlanması amaçlanmıştır.

Aktarılabilirlik ise, bir çalışmada elde edilen bulguların başka çalışmalara ve durumlara uyarlanabilme durumudur. Çalışmanın dış geçerliği akatarılabilirliğini yansıtmaktadır. Bu çalışmada ölçüt örneklemeye yer verilerek dahil etme kriterlerin ortaya konulması, dahil edilen makalelere yönelik ayrıntılı verilere yer verilmesi çalışmanın aktarılabilirliğini ortaya koymaktadir.

Güvenilebilirlik, çalışmanın sonunda elde edilen bulguların kendi aralarındaki uyumu ve tutarlılıkları olarak açıklanmıştır. Bu çalışmada araştırma yönteminin ve araştırma aşamalarını ayrıntılı açıklamasına yer verilmesi ile çalışmanın güvenirliği ortaya konmaya çalışılmıştır. Teyit edilebilirlik, çalışmadan elde edinilen bulguların içeriklerinin, uygulamada fikri incelenen katılımcların ifadelerine ve deneyimlerine göre elde edildiğini ispat etmek anlamına gelmektedir (Shenton, 2004). Bu çalışmada bireysel katılımcllara yer verilmediği için toplanan verilerden çıarılan anlam bulgu ve yorumlara yönelik oluşturulan bir raporun katılımc teyidini almak için katılımcılara gönderilmesi işlemine başvurulmamıştır.

Ayrıca çalışmada içerik analizinde veri seti iki kodlayıcı tarafından kodlamış ve kodlayıcılar arasındaki uyum değerlerinin belirlenmesinde kodlayıc1 güvenirliği Miles ve Huberman (1994) formülü ile [görüş birliği / (görüş birliği + görüş ayrılı̆̆ı) x 100] hesaplanmış ve kodlayıcılar arasındaki uyum oranı \%93 olarak tespit edilmiştir. Bu formüle göre kodlayıcılar arası görüş birliğinin en az \% 80 olması beklenmektedir (Miles ve Huberman, 1994). Dolayısıyla bu çalışmada ulaşılan uyum oranı sonuçların güvenilir olduğunu göstermektedir.

\section{Verilerin Analizi}

Yapılan araştırmada verilerin analizi içerik analizi yöntemi ile gerçekleştirilmiştir. İçerik analizi, amaçlarının belirlenmesi, kavramları tanımlamak, 
analiz birimlerini belirlemek, konu ile ilgili verilerin yerini belirlemek, mantıksal bir yapının geliştirilmesi, örneklem planı geliştirmek, kodlama kategorilerini belirlemek ve verilerin analizi bölümlerinden oluşmaktadır (Büyüköztürk vd., 2009). Analiz süreci veri toplama süreci ile eş zamanlı ilerleyebilmektedir. Kategori oluşturma aşamasında veri analizi de yapılabilmektedir. İlerleyen zamanlarda analize ağırlık verilmektedir (Merriam, 2013).

$\mathrm{Bu}$ çalışmada toplanan veriler önce kavramsallaştırılmıştır. Daha sonra ortaya çıkan kavramlara göre düzenlenmiş, buna göre veriyi açıklayan temalar saptanmıştır. Toplanan veriler içerik analizi uygulanarak veriler arasında yer alan anlamlı bölümlere isim verilmiştir. Elde edilen kavramlar birbirleriyle belirli bir tema altında sınıflandırılmıştır. Kavramların incelenmesi sonucunda birbirleriyle olan ilişkileri ortaya çıkarılmıştır. Daha önce de belirtildiği gibi okul öncesi eğitim programı alanında yapılmış makalelerden 2013-2020 yılları arasında yapılan 201 makale incelenmiştir. Bu makaleler eğitim programlarında en çok değinilen konulara göre grupland1rılmıştır. Makalelerin özellikleri MAXQDA programı kullanılarak analiz edilmiş olup şekil ve grafiklerde gösterilmiştir.

\section{Bulgular}

Çalışmada elde edilen bulgular araştırma soruları temel alınarak analiz edilmiş ve aşağıda sunulmuştur.

Araştırmanın birinci alt amacı Okul Öncesi Eğitim Programına etki eden okul dışı faktörler nelerdir? şeklinde ifade edilmiştir. Tema ve kodlara ait bulgular Şekil 1'de verilmiştir. 


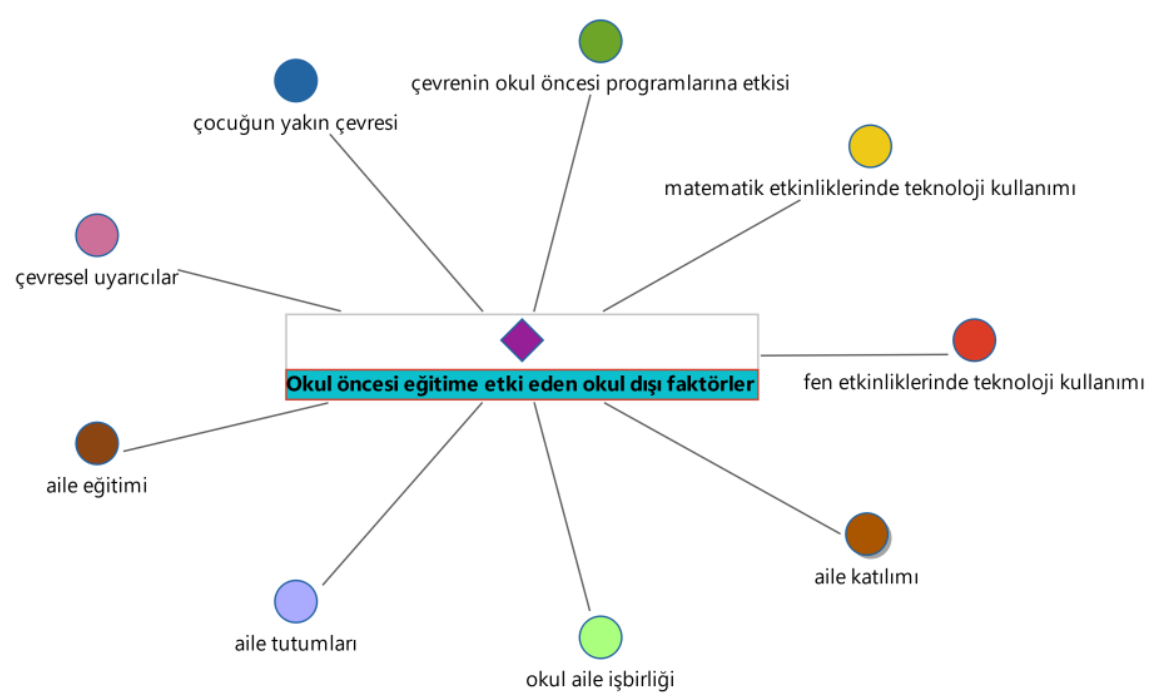

Şekil 1. Okul öncesi eğitime etki eden okul dışı faktörler

Şekil 1'de görüldüğü gibi okul öncesi eğitime etki eden okul dışı faktörler aile, çevre ve teknoloji temaları altında toplanmıştır. Aile teması incelendiğinde 25 adet makalede ailenin okul öncesi eğitime olan katkısından bahsedildiği görülmüştür. "Okul öncesi eğitimde ailenin eğitime dahil olmasl, çocuğun çok yönlü gelişimine katkı sağlamaktadır." (M1,syf:157), "Aile desteğinden yoksun okul öncesi eğitimin hedeflerine tam olarak ulaşılması beklenemez. Annebaba katılımı sağlanmaksızın okul öncesi eğitimde istenen kalitenin yakalanması zordur." (M2, syf:57), "Okul öncesi eğitim kurumlarında uygulanan eğitim programları ne kadar kaliteli olursa olsun aileler tarafindan desteklenmedikçe istenen hedeflere ulaşmak güçtür." (M3, syf:28), "ailelerden beklentileri, ailelerin seminerlere, konferanslara katılarak bilgi sahibi olmalarn gerektiği; aileler ve öğretmenlerin okul yönetiminden beklentileri ise toplantı ve konferanslarm arttırlarak yapılması gerektiği yönündedir." (M4, syf:59), "Aile katılımı çalışmalarının çocukların bilişsel, dil, sosyal duygusal, psikomotor ve fiziksel gelişim gibi tüm gelişim alanlarm ve aynı zamanda akademik başarılarm da desteklediği bilinmektedir" (M5, syf:22), "Çocuğun sağlıkl bir şekilde büyüyebilmesi, gelişebilmesi ve öğrenmeye karşı olumlu tutumlar geliştirebilmesi için nitelikli bilişsel uyarıcılarn, zengin dil etkileşimlerinin, olumlu sosyal ve duygusal deneyimlerin çocuğa sunulduğu ve çocuğun bağımsızlığının desteklendiği bir çevrenin yaratılmasına ihtiyaç vardır. Bu ise ancak sağllkh bir aile ortamı ve nitelikli bir okul öncesi eğitim ile mümkündür. (M6, 
syf:43), "Çocuklar zamanlarmın büyük bir bölümünü aile ortamında geçirdiklerinden her aile bireyi çocuğun potansiyelini ortaya koyması, kullanması ve kendini gerçekleştirmesi için uygun ortam ve koşullar hazırlama, onu teşvik etme, başarısını arttırma ve destekleme için potansiyel bir güce sahiptir. (M7, syf:197), "Çocukların okul öncesi eğitime dahil olabilmeleri açısından ebeveynlerin bilinçlendirilmesi, yönledirilmesi ve gerekli durumlarda desteklenmesi gerekir. Çocuk üzerinde en büyük hak ve sorumluluğa sahip aileler bu şekilde çocuklarmmn erken eğitim almalar konusunda teşvik edilebilir. (M8, syf:53), "Başarılı bir okul öncesi eğitim için ailelerde eğitimin içine katılarak, anne- baba da eğitim sürecine dahil edilmelidir."(M9, syf:681), "Ailenin çocuğun eğitim sürecine katıllmında, okul ve ailede verilen eğitim birbirinden kopuk olmamahldır." (M10, syf:63), "Aile ve öğretmenin etkili bir iletişim içerisinde bulunmasının çocuğun gelişimi ve eğitimi açısından oldukça önemli olduğu unutulmamahdır." (M11, syf:176), "Bir bakıma, anne ve babalar sıfir altı yaş döneminde hem çocuklarm tüm ihtiyaçlarımın karşılanmasında en yakınında olan kişiler, hem de ilk öğretmenleridirler. Kişiliğin gelişimsel temellerinin sıfir altı yaş döneminde atıldı̆̆̆ göz önüne alındığında, eğitsel kimliğin belirlenmesinde ebeveynlerin rollerinin önemi daha da iyi anlaşılmış olur." (M12, syf:48), "Erken dönemde çocuğun çevresi önce aile daha sonra okul öncesi eğitim kurumlarıdır." (M13, syf:1175) kısımları okul öncesi eğitimde ailenin önemini kanıtlar nitelikte olan cümleler olarak yer almaktadır. (M103, syf:66), (M104, syf:743), (M105, syf:50), (M106, syf:186), (M107, syf:1312), (M108, syf:61), (M109, syf:466), (M110, syf:2), (M115, syf:30), (M120, syf:98), (M130, syf:230) ve (M187, syf:403) numaralı makalelerde konu ile ilgili benzer nitelikte cümleler yer almaktadır.

Çevre teması incelendiğinde 25 adet makalede çevrenin okul öncesi eğitim üzerindeki etkisinin yer aldığı gözlemlenmiştir. "Çocuk, okul öncesi dönemde çeoresel uyarıcılara karşı oldukça duyarlıdır. Olumlu ya da olumsuz sayılabilecek tüm davranışları hızlıca kazanır." (M3, syf:24), "Çocukların ne kadar keşfedebileceği, neler öğrenebileceği ve hangi hızla öğrenebileceği onlarm çevresinin ne kadar destekleyici olduğuyla ve onlara ne gibi olanaklar sunulduğuyla yakmdan ilişkilidir." (M6, syf:43), "Çocuğun sağglkh bir şekilde büyüyebilmesi, gelişebilmesi ve öğrenmeye karşı olumlu tutumlar geliştirebilmesi için nitelikli bilişsel uyarıcılarm, zengin dil etkileşimlerinin, olumlu sosyal ve duygusal deneyimlerin çocuğa sunulduğu ve çocuğun bağımsizlı̆̆ının desteklendiği bir çevreye ihtiyaç vardır." (M7, syf:196), "Okul öncesi dönem bireylerin tüm gelişim alan ve özelliklerinde hızh gelişim gösterdikleri bir dönemdir. Aynı zamanda potansiyellerini daha ileri 
boyutlara taşıyabilmeleri açısından en duyarl ve hazır oldukları, önemli bir dönemdedir. Bireylerin bu dönemde yaşadikları olumlu veya olumsuz deneyimler onlarm gelecekteki yaşamların ve bunun bir parçası olan öğrenme hayatların çok yakından etkileyecektir." (M8, syf:44), "Okul öncesi eğitim; doğumdan ilköğretime kadar olan çocukluk yıllarını içine kapsayan, 0-6 yaş çocuklarının gelişimsel özelliklerine uygun, uyarıcı çeore olanaklarım sunan, çocuklarm gelişimlerini ahlaki ve kültürel değerler doğrultusunda en iyi biçimde yönlendiren eğitim sürecidir."(M10, syf:62), "Araştırmalar, çocuğun neleri, hangi hızla ve nasıl öğrenebileceğinin çevre desteği ve sunulan olanaklarla yakından ilişkili olduğunu ortaya çıkarmıştır." (M11, syf:161), "Değgrlerin çocuğa kazandirlmasinda çeore faktörü özellikle de okul çok büyük bir öneme sahiptir." (M14, syf:1077), “Gelişimin ve öğrenmenin en hızlı olduğu dönem olarak ele alman erken çocukluk döneminde, çocuklar çeorelerini gözlemleyerek ve inceleyerek bilgiye ulaşmaya çalışırlar."(M16, syf:1173), “2013 Okul öncesi eğitim programı günlük yaşam deneyimlerinin ve yakın çevre olanaklarının eğitim amaçlı kullanılmasını teşvik eder." (M20, syf:46), "Okul öncesi dönem çocuğun çevreden gelen etkilere en açı olduğu dönemdir." (M92, syf:1) kısımları okul öncesi eğitimde çevrenin önemini açıklayan cümleler olarak gözlemlenmiştir. (M112, syf:796), (M113, syf:105), (M118, syf:3), (M121, syf:65), (M122, syf:1107), (M123, syf:2), (M124, syf:181), (M125, syf:65), (M126, syf:422), (M127, syf:193), (M128, syf:109), (M131, syf:549), (M143, syf:290), (M173, syf:923) ve (M185, syf:52) numaralı makalelerde benzer nitelikte cümleler yer almaktadır.

Teknoloji teması incelendiğinde 12 makalede teknolojinin okul öncesi eğitim programı üzerindeki etkilerinden bahsedildiği görülmüştür. "Son yüzylda matematik, fen ve teknoloji alanlarnnda yaşanan gelişmeler, ülkelerin bu alanlara eğilimini artırmış ve hazırladıkları eğitim politikalarında fen ve matematik eğitimine daha fazla odaklanmalarına yol açmıştır). Bu doğrultuda, erken çocukluk yillarımın birçok matematik kavramının temellerinin kazanıldığ s sihirli yıllar olduğu düşünüldü̈̆ünde okul öncesi eğitim alan ve almayan tüm yaş grubu çocuklarm matematik becerilerinin incelenmesinin önemli olduğu düşünülmektedir (M18, syf:396-414), “Okul öncesi dönem bireyin temel fen kavramları kazanacă̆ı ve fen ve teknolojiye ilişkin olumlu veya olumsuz tutum geliştirebileceğgi bir zaman dilimi olduğundan, bu alanda görev yapacak öğretmen adaylarmın nitelikli yetiştirilmesi önem taşımaktadır." (M28, syf:99), "Gelişen bilişim teknolojileri insanların kendilerine ve çeorelerine olan bakış açlarım yeniden şekillendirmiş, buna paralel olarak eğitim alanında da değişim ve gelişimin aynı hızla gerçekleşmesini kaçınılmaz hale 
getirmiştir." (M30, syf:123), "Bilim ve teknoloji alanındaki hızl ilerleme, bilginin en değerli kazanım olduğu gerçeğini daha net bir biçimde önümüze koymaktadır. Bir toplumun geleceğini inşa edecek olan çocuklarm ve gençlerin tüm bu değişim sürecine yabancı kalmamaları, çă̆gn gerektirdiği bilgi ve donanıma sahip olmaları ise, eğitim sistemleri ve bilimsel gelişmeler arasında uyumun sağlanabilmesi ile yakından ilgilidir." (M32, syf:116) kısımları incelendiğinde okul öncesi eğitim programında teknolojinin önemi ile ilgili cümleler gözlemlenmiştir. (M119, syf:565), (M133, syf:197), (M135, syf:832), (M141, syf:138), (M151, syf:245), (M152, syf:160), (M163, syf:7) ve (M179, syf:4) numaralı makalelerde benzer nitelikte cümleler yer almaktadır.

Araştırmanın ikinci alt amac1 "Okul öncesi eğitim programlarmın özellikleri nelerdir?" şeklinde ifade edilmiştir. Tema ve kodlara ait bulgular Şekil 2'de verilmiştir.

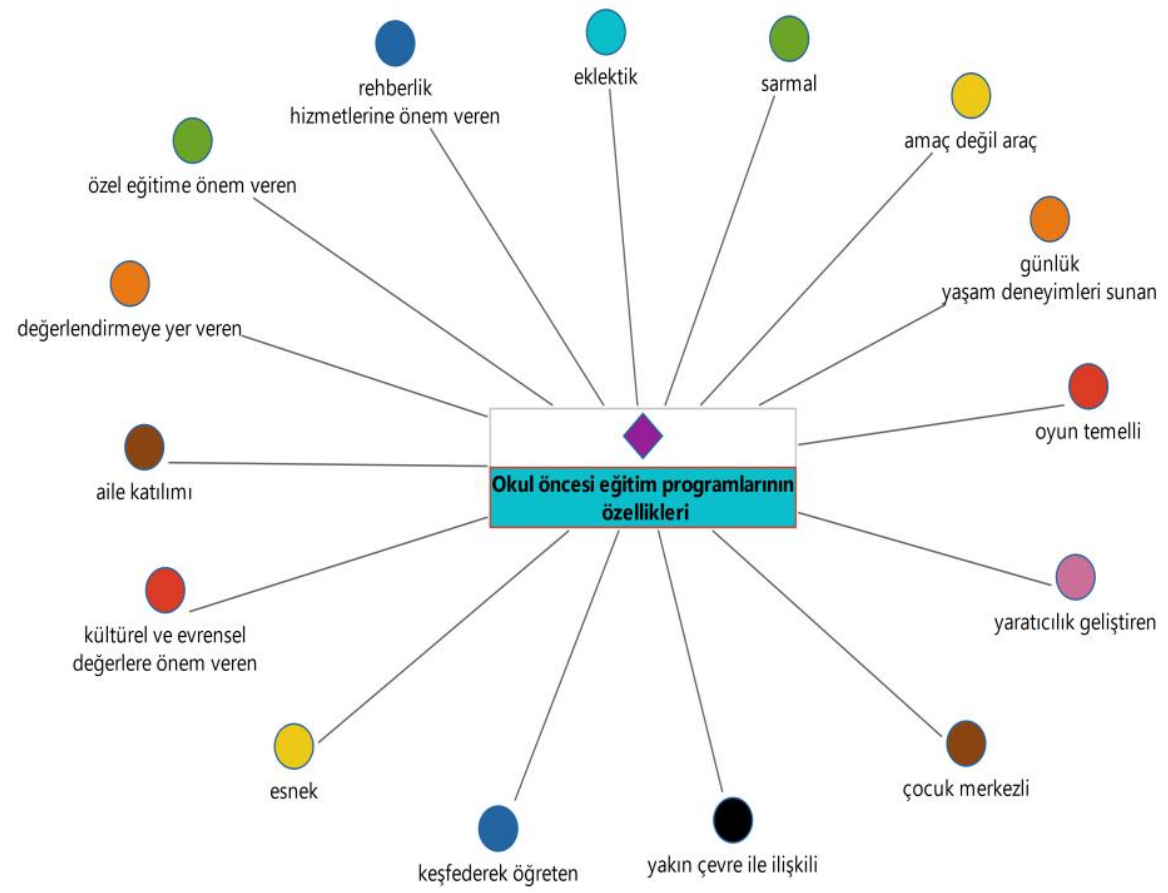

Şekil 2. Okul öncesi eğitim programının özellikleri

Şekil 2'de de görüldüğü üzere okul öncesi programının özellikleri çocuk merkezli, esnek,sarmal, eklektik, dengeli, oyun temelli, keşfederek öğreten, yaratıcılık geliştiren, günlük yaşam deneyimleri ve yakın çevre ile ilişkili, 
amaç değil araç, kültürel ve evrensel değerlere önem veren, aile katılımına yer veren, değerlendirme yapan, özel eğitime önem veren ve rehberlik hizmetlerine önem veren olmak üzere 15 tema altında toplanmıştır. Programın çocuk merkezli olması teması incelendiğinde 10 adet makalede bu konuya yer verildiği görülmüş̧ür. "Gelişimsel bir programdır (Çocuğun bütünsel gelişimini destekler, bütüncül bir yaklaşımla, çocuğun sosyal ve duygusal, motor, bilişsel, dil gelişim alanlarn ile öz bakım becerilerini birlikte ele alır.)., Sarmal özellik gösterir, Model olarak "eklektik"tir., Çocuk merkezlidir." (M90, syf:2231), "MEB 2013 programı çocuk merkezli bir programdır." (M63, syf:665), "Çocuk merkezli olan program, çocuğun oyun yoluyla, keşfederek öğrenmesini ve yaratıcliğının geliştirilmesini ön plana almakta, öğrenme ortamlarmm öğrenme merkezleri şeklinde düzenlenmesini, süreç içinde günlük yaşam deneyimleri ve öğrenme ortamlarmdan yararlanılmasımı, özel gereksinimli çocuklar için uyarlamaların yapılmasını ve değerlendirmenin çok yönlü yapılmasını öngörmektedir." (M93, syf:4), "Çocuk merkezli programlar her çocuğun ilgi, ihtiyaç ve yetenekleri doğrultusunda oluşturulduğundan, çocuklara tercih yapma ve karar verme imkanı tanıdığından, kaynaştırma ve farklliklara karşı duyarl olduğundan, çocuklar ve yetişkinler arasında sosyal etkileşime firsat verdiğinden, çocuklara etkinlik başlatma ve yönlendirme fırsatı sunduğundan dolayı katılım hakkının niteliklerini destekler bir çerveve oluşturmaktadır." (M89, syf:206) cümleleri güncellenen programin çocuk merkezli olarak hazırlandığını kanıtlar niteliktedir. (M20, syf:46), (M23, syf:105),(M91, syf: 682), (M95, syf:65), (M96, syf:30) ve (M97, syf:383)'de benzer cümlelerin yer aldığ gözlemlenmiştir.

İkinci tema olan programın esnek olması incelendiğinde 11 adet makalede konuyla ilgili cümleler yer aldığı gözlemlenmiştir. "Bu eğitim programı çocuk merkezli ve esnek bir program olarak hazırlanmıştır. Ancak programın genelde çocuk haklarn özelde ise çocuğun katılım hakkına yer verme durumunun değerlendirilmesi yapılmamıştır." (M89, syf:206), "Gelişimsel bir programdır (Çocuğun bütünsel gelişimini destekler, bütüncül bir yaklaşımla, çocuğun sosyal ve duygusal, motor, bilişsel, dil gelişim alanlarn ile özbakım becerilerini birlikte ele alır.)., Sarmal özellik gösterir, Model olarak "eklektik" tir., Çocuk merkezlidir., Esnektir." (M90, syf:2231), "Programda, yaparak-yaşayarak öğrenme ilkesi temel alınmış ve farklı imkanlara sahip bölgelerde uygun etkinliklere imkan sağlayan esnek bir program olma özelliği taşımaktadır" (M63, syf:665), "Program çocuk merkezli, esnek, dengeli ve oyun temellidir." (M20, syf:46), "Program özelliklerine bakıldığında MEB Okul Öncesi Ĕ̆itim Programı çocuk merkezli, esnek, oyun temelli bir programdır." 
(M23, syf:105), "okul öncesi eğitim programmın kazanım ve göstergeler üzerine yapılandırıldığı, belli bir içeriğe sahip olmadı̆̆g, öğretmenin program planlamada esnekliğe sahip olduğu görülmektedir." (M24, syf:1087) cümlelerinde programın esnek olarak düzenlendiği gözlemlenmiştir. (M93, syf:22), (M98, syf:314), (M97, syf:383), (M62, syf:495), (M51, syf:491) numaralı makalelerde de programın esnek olmasını destekleyen nitelikte benzer cümleler yer almaktadır.

Üçüncü tema olan programın sarmal olması incelendiğinde 4 adet makalede konuyla ilgili cümleler olduğu görülmüştür. "2012 Okul Öncesi Eğitim Programı, çocuklarm gelişim düzeylerine ve özelliklerine dayanan bu bağlamda, tüm gelişim alanlarmın geliştirilmesini esas alan, "gelişimsel" bir programdır. Program yaklaşımı olarak "sarmal" özellik gösteren bu program, model olarak "eklektik"tir." (M98, syf:323), "Okul öncesi eğitim programı okul öncesi dönemde çocuğun tüm gelişimini destekleyecek eklektik ve sarmal bir programdır." (M97, syf:382), "Erken çocukluk ile ilkokul arasındaki kurulacak güçlü bir köprü ve sarmal eğitimsel devamlılık pozitif öğretmen-öğrenci ilişkileri ve öğrenme ortamlar sağlar." (M24, syf:1085) cümlelerinde programin sarmal yapıda olduğunu gösteren cümleler yer almaktadır. (M90, syf:2230)'da programın sarmallığına dair benzer cümleler bulunmaktadır.

Dördüncü tema olan programın eklektik olması incelendiğinde 8 adet makalede konu ile ilgili cümleler olduğu görülmüştür. "Güncel okul öncesi eğitim programı 2013 yılında MEB tarafından yayımlanmıştır. Çocuk merkezli, esnek, eklektik, dengeli, oyun temelli keşfederek öğrenme gibi özellikleri barındıran bu program dokuz bölümden oluşmaktadır." (M23, syf:105), "Mevcut okul öncesi eğitim programmda doğrudan tarih, coğrafya ya da vatandaşlık ile ilgili kazanımlara sahip olmasa bile programin eklektik ve esnek yapısı (MEB, 2013) örtük olarak ya da tematik yaklaşım desteği ile temel bilgi ve beceriler kazandirabilir." (M24, syf:1100), “Okul Öncesi Eğitim Programmın eklektik özelliği şöyle açıklanmıştır. "Çeşitli ülkelerdeki okul öncesi eğitimi programları incelendiğinde, programlarm farkl yaklaşım ve modelleri temel alarak oluşturulduğu görülmüştür. Bu programda 21. yüzyllın gereksinim duyduğu bireyi yetiştirmek, ulusal özellik ve gereksinimleri karşılamak amacryla farkh öğrenme kuram ve modellerindeki çocuk merkezli uygulamalardan yararlanılarak bir senteze ulaşılmıştır" (M96, syf:30), "Çocuğun tüm gelişim alanlarm dengeli biçimde desteklemeyi hedeflemesi bakımından gelişimsel ve dengeli, öğrenmelerin kahculığın hedeflemesi ve bilimsel çalışmalara dayanması bakımından da eklektiktir." (M93, syf:4), "Okul öncesi eğitim programı model olarak eklektiktir." (M90, syf:2239), "Okul öncesi eğitim programı okul önce- 
si dönemde çocuğun tüm gelişimini destekleyecek eklektik ve sarmal bir programdır." (M97, syf:382) cümleleri programın eklektik olduğunu kanitlar niteliktelerdir. (M98, syf:315) ve (M75, syf:2) numaralı makalelerde de programın eklektik olduğunu anlatan benzer cümleler yer almaktadır.

Beşinci tema olan programın dengeli olması incelendiğinde toplam 7 makalede konuyla ilgili cümleler geçtiği görülmüştür. "Program esnektir, sarmaldır, eklektiktir, dengelidir ve oyun temelli bir programdır." (M63, syf:665), "Program çocuğun tüm gelişim alanlarm dengeli biçimde desteklemeyi hedeflemesi bakımından gelişimsel ve dengelidir." (M93, syf:4), "Kitaplardaki çalışma sayfaları MEB 2013 OÖEP'ında yer alan kazanmmlara ve kavramlara kapsaml ve dengeli bir şekilde yer vermelidir." (M90, syf:2242), "Programm temel özellikleri çocuk merkezli, dengeli ve oyun temelli olmasıdır." (M48, syf:204), "Program çocuk merkezli, esnek, dengeli ve oyun temellidir." (M20, syf:46) k1sımlarında da görüldüğü gibi yeni düzenlenen program dengeli şekilde oluşturulmuştur. (M97, syf:383) ve (M23, syf:105)'te de programın dengeli hazırlandığını kanıtlayan niteliklerde benzer cümleler yer almaktadır.

Altınc tema olan programin oyun temelli olması incelendiğinde toplam 20 makalede konuyla ilgili cümleler geçtiği görülmüştür. "Çocuk merkezli olan program, çocuğun oyun yoluyla, keşfederek öğrenmesini ve yaratıcilı̆̆ını geliştirilmesini ön plana almakta, öğrenme ortamlarmm öğrenme merkezleri şeklinde düzenlenmesini, süreç içinde günlük yaşam deneyimleri ve öğrenme ortamlarmdan yararlanılmasımı, özel gereksinimli çocuklar için uyarlamaların yapılmasını ve değerlendirmenin çok yönlü yapılmasım öngörmektedir." (M93, syf:4), "Program çocuk merkezli, esnek, dengeli ve oyun temellidir." (M20, syf:46), "MEB 2013 programı oyun temelli bir programdır." (M63, syf:665), "Milli Eğitim Bakanlı̆̆ tarafindan 2013 yılında uygulamaya koyulan Okul Öncesi Eğitim Programının temel özelliklerinden biri oyun temelli olmasıdır." (M68, syf:804), "Programda kazanım ve göstergeler ele alınıken oyunun bir yöntem velveya etkinlik olarak kullanılması özellikle önerilmektedir. Oyun aracılığıyla öğrenme bu programın ve okul öncesi eğitiminin ayrılmaz parçası olarak görülmektedir." (M48, syf:204), "MEB Okul Öncesi Ĕ̆itim Programı, bireysel farklilklara, demokratik öğrenme ortammın yaratılmasına, oyun temelli öğrenmeye, değerlendirmeye ve aile katılımina vurgu yapmıştır." (M23, syf:105) kısımlarında görüldüğü üzere okul öncesi eğitim programında oyun önemli bir yer kaplamaktadır. (M90, syf:2230), (M98, syf: 315), (M64， syf:27), (M45， syf:169), (M24， syf:1085), (M60, syf:46), (M62, syf:495), (M174, syf:115), (M181, syf:63), (M197, syf:2163), (M201, syf:189) ve 
(M132, syf:527) numaralı makalelerde de okul öncesi eğitim programında oyunun önemli bir yere sahip olduğuna dair benzer cümleler olduğu gözlemlenmiştir.

Yedinci tema olan programın keşfederek öğretmesi başlığı incelendiğinde toplam 5 makalede konuyla ilgili cümleler geçtiği görülmüştür. "Programda çocuklarm keşfederek öğrenmelerine öncelik verilmektedir ve çocuklarm yaratıcllklarn desteklenmektedir." (M63, syf:665), "Çocuk merkezli olan program, çocuğun oyun yoluyla, keşfederek öğrenmesini ve yaratıcllı̆̆ınn geliştirilmesini ön plana almakta, öğrenme ortamlarmm öğrenme merkezleri şeklinde düzenlenmesini, süreç içinde günlük yaşam deneyimleri ve öğrenme ortamlarından yararlanılmasımı, özel gereksinimli çocuklar için uyarlamaların yapılmasın ve değerlendirmenin çok yönlü yapılmasını öngörmektedir." (M93, syf:4), "Programın temel özellikleri arasinda yer alan 'Çocuk merkezlidir', 'Keşfederek öğrenme önceliklidir', 'Öğrenme merkezleri önemlidir', 'Değerlendirme süreci çok yönlüdür' özelliklerinin katıllım hakkna doğrudan yer verdiği saptanmıştır." (M89, syf:208), "Bu programm temel özellikleri; çocuk merkezli olması esnek olması, temalarm/konuların amaç değil araç olarak vurgulanması, oyun temelli olması, keşfederek öğrenme öncelikli olması, öğrenme merkezlerinin öneminin arttırılması yaratıcılğ̆ın geliştirilmesinin ön planda tutulmast, evrensel ve toplumsal değerlere yer verilmesi, değerlendirme sürecinin çok yönlü olması, özel gereksinimli çocuklar için uyarlamalara yer verilmesi, rehberlik hizmetlerine önemin artması ve öğretmene özgürlük tanımasıdır" (M98, syf:315), "Program keşfederek öğrenme önceliklidir." (M90, syf:2231) kısımlarında görüldüğü üzere okul öncesi eğitim programında keşfederek öğrenme önemli bir yer kaplamaktadır.

Sekizinci tema olan okul öncesi eğitim programının yaratıclık geliştirmesi incelendiğinde toplam 7 makalede konuyla ilgili cümlelerin geçtiği görülmüştür. "Programda çocuklarm keşfederek öğrenmelerine öncelik verilmektedir ve çocuklarm yaratıcllklar desteklenmektedir." (M63, syf:665), "Okul öncesi eğitim programında yer alan kazanımlar ilkokul programinda yer alan problem çözme stratejileri geliştirebilme, akıl yü-rütme, ilişkilendirme, karar verme gibi zihinsel işlem becerileri ile, sorumluluk alma ve yerine getirme, eleştirisel düşünme ve iletişim kurma, çevre bilinci ve yaratıcllk gibi becerileri de kapsar." (M97, syf:382) kısımlarında görüldüğü üzere okul öncesi eğitim programı yaratıcılığı geliştirmeye yönelik hazırlanan bir programdır. (M100, syf:72), (M101, syf:85), (M102, syf:54), (M90, syf:2239) ve (M158, syf:2) numaralı makalelerde benzer nitelikte cümleler olduğu görülmüştür. 
Dokuzuncu tema olan okul öncesi eğitim programının günlük yaşam deneyimleri ve yakın çevre ile ilişkili olması incelendiğinde toplam 7 makalede konuyla ilgili cümlelerin geçtiği görülmüsstür. "Programda günlük yaşam ve yakın çevre olanaklarmmn kullanılması desteklenmektedir." (M63, syf:665), "Program günlük yaşam deneyimlerinin ve yakın çeore olanaklarmmn eğitim amaçh kullamlmasını teşvik eder." (M20, syf:46), "Çocuk merkezli olan program, çocuğun oyun yoluyla, keşfederek öğrenmesini ve yaratıcllı̆̆ının geliştirilmesini ön plana almakta, öğrenme ortamlarmın öğrenme merkezleri şeklinde düzenlenmesini, süreç içinde günlük yaşam deneyimleri ve öğrenme ortamlarmdan yararlanılmasın, özel gereksinimli çocuklar için uyarlamalarn yapılmasını ve değerlendirmenin çok yönlü yapılmasını öngörmektedir." (M93, syf:4), "Çocuklara sosyal alan öğretimi kendileri, çeorelerinde insanlar, yaşadiklarn yakın çeore hakkında bilgi birikimi ve beceri edinmelerini sağlar." (M24, syf:1086) kısımlarında da görüldüğü üzere okul öncesi eğitim programında günlük yaşam deneyimleri ve yakın çevre ile ilişkilere yer verildiği görülmüştür. (M97, syf:383), (M90, syf:2239), (M66, syf:69) numaralı makalelerde de benzer cümlelere rastlanmaktadır.

Onuncu tema olan program amaç değil araçtır başlığı incelendiğinde toplam 6 makalede konuyla ilgili cümlelerin geçtiği görülmüştür. "Türkiye'de ise 2013 okul öncesi programmmn özelliklerine bakıldığmda, tema bir amaç olarak değil bir araç olarak yer almakta, bu bağlamda öğretmen kazanım ve göstergelere uygun konular araç olarak belirlemektedir." (M24, syf:1087), "Programda öngörülen hedef ve hedef davranışlara ulaşılması için konular esas alınmıştır. Konuları öğretimi amaç değil hedef ve davranışlara ulaşılması için araçtır." (M95, syf:66), "2013 okul öncesi eğitim programinda temalar/konular amaç değil araçtır." (M20, syf:46) kısımlarında görüldügüü üzere çocuklara verilecek olan temalar amaç değil araçtır. (M90, syf:2230), (M97, syf:383) ve (M98, syf:315)'de bu durumu kanitlar nitelikte benzer cümlelere rastlanmaktadır.

On birinci tema olan programın kültürel ve evrensel değerlere önem vermesi incelendiğinde toplam 9 makalede konuyla ilgili cümlelerin geçtiği görülmüştür. "Okul Öncesi Eğitim Programında öğrenme merkezleri önemlidir, kültürel ve evrensel değerleri dikkate alır." (M24, syf:1090), "Okul öncesi eğitim program kültürel ve eorensel değerleri dikkate alır."(M20, syf:46), "Programda çocuğun yaşadığı kültürün değerlerini tanmmalarnna ve kültürel ve evrensel değerleri benimsemelerine önem verilmektedir." (M63, syf:665) kısımlarında görüldüğ̈̈ üzere güncellenen okul öncesi eğitim programı kültürel ve evrensel değerlere değer verecek şekilde hazırlanmıştır. (M97, syf:383), (M34, syf:91), (M10, 
syf:65), (M55, syf:70), (M90, syf:2239) ve (M14, syf:1076)'te de bu durumu ifade eden benzer cümleler bulunmaktadır.

On ikinci tema olan aile katılımı incelendiğinde toplam 14 makalede konuyla ilgili cümlelerin geçtiği görülmüş̧ür. "Nitelikli okul öncesi eğitim programlarının bileşenleri; program, aile katılımı, aile-öğretmen-çocuk arasındaki ilişkiler, eğitim ve değerlendirme olarak ifade edilmektedir." (M63, syf:664), "Aile katılımı, okulöncesi eğitim programmın önemli bir parçasını oluşturmalı ve kurumda verilen eğitimin devamlllı̆̆l, ailenin çocuğunu daha iyi tanıması, program konusunda bilgi sahibi olabilmesi gibi nedenlerle mutlaka planl olarak yapılmalidır." (M2, syf:58), "okul öncesi eğitim kurumlarında uygulanmakta olan okul öncesi eğitim programı aile katılımı çalışmalarını da içermektedir." (M13, syf:1176), "Programda çocuğun aktif katılımının sağlanmasını amaçlayan, çocuğun yaparak yaşayarak öğrenmesinin, farklı deneyimler kazanmasının, aile katılımını ve çocuklar arasindaki bireysel farklilklarn ve ilgilerinin göz önünde bulundurulması temel özellik olarak benimsenmiştir." (M83, syf:336), "Okul öncesi eğitimin temel ilkeleri ile ilgili olarak MEB Okul Öncesi Ĕ̆itim Programı, bireysel farklliklara, demokratik öğrenme ortamının yaratılmasına, oyun temelli öğrenmeye, değerlendirmeye ve aile katılımına vurgu yapmıştır." (M23, syf:105), "Okul öncesi eğitim alanında çocuklar üzerinde yapılan araştırmalar, aile katılımı sağlayan programlarda yetişen çocuklarm gelişimlerindeki olumlu etkilerin kahıcı olduğunu ortaya koymaktadır." (M6, syf:43), "aile katılımı çocukların sağlkkl gelişimlerini sürdürebilmesi ve okula hazırlanması amactyla düzenlenen eğitim etkinliklerini gerçekleştirmek için öğretmenin ve aile bireylerinin birlikte hareket ederek çaba göstermeleri gerekmektedir." (M9, syf:681), "Okulöncesi eğitim programlarnna aile katılımi; okul ve ev arasındaki devamlilığı sağlayacaktır." (M97, syf:383), "okul öncesi eğitimin amaç ve ilkeleri, kazanımlar, öğrenme merkezleri, etkinlikler, planlama, aile katılımı ve değerlendirmedir." (M93, syf:8) kısımlarında okul öncesi eğitim programında aile katılımının önemine vurgu yapılmaktadır. (M98, syf:318), (M48, syf:204), (M1, syf:158), (M95, syf:72) ve (M34, syf:96) numaralı makalelerde de konuyla ilgili benzer cümleler yer almaktadır.

On üçüncü tema olan değerlendirme incelendiğinde toplam 13 makalede konuyla ilgili cümlelerin geçtiği görülmüştür. "Gelişimsel açıdan tutarl programlarda "değerlendirme" oldukça önemlidir." (M94, syf:3), "Okul öncesi eğitim programın değerlendirme araştırmalarmın, öğretmen görüşlerine ve öğrenci başartsına dayah, programin tamamın veya belirli bir bölümünü ele alan çahısmalarm olduğu görülmektedir."(M93, syf:5), “Okul Öncesi Eğitim Programinda değerlen- 
dirme süreci çok yönlüdür." (M89, syf:208), "Değerlendirme süreci programm güçlü ve zayıf yönlerini ortaya çıkarır." (M95, syf:63), "Okul öncesi eğitimde değerlendirme süreci çok önemlidir." (M98, syf:321), "Okul öncesi eğitim programında ana ögelerden biride değerlendirme sürecinin olması ve çok yönlülü̈̆̈̈̈dür." (M97, syf:383), "Okul öncesinde çocukları tanımak, değerlendirmek ve eğitim planını ona göre şekil vermek oldukça geniş ve kapsamlı bir süreç gerektirir." (M29, syf:202), "Değerlendirme, her bir öğretim sürecinin sonunda yer verilmesi gereken bir bölümdür." (M34, syf:95), "Yeni okul öncesi eğitim programlar ile ilgili olarak da çeşitli değerlendirmeler yapılarak programın sürdürülmesi veya geliştirilmesine ilişkin kararlar verilmelidir." (M91, syf:662) kısımlarında görüldüğü üzere okul öncesi eğitim programında değerlendirmeye önem verilmektedir. (M90, syf:2230), (M63, syf:664), (M167, syf:903) ve (M73, syf:693)'te okul öncesi eğitim programında değerlendirmenin önemini kantlar nitelikte cümleler yer almaktadır.

On dördüncü tema olan programın özel eğitime önem vermesi incelendiğinde toplam 11 tane makalede konuyla ilgili cümlelerin yer aldığı gözlemlenmiştir. “Özellikle okul öncesi eğitim alanında özel eğitime ihtiyacı olan çocukları belirlemenin önemli bir gayret gerektirdiği herkes tarafindan kabul edilmektedir." (M63, syf:668), "program bu hassasiyetle uygulamldı̆̆ı zaman özel eğitime ihtiyacı olan çocuklar içinde kullanulabileceği ve program eğitimcinin deneyimleri ile birleştiğinde ve çocuklarm çeşitli özelliklerine göre uyarlandığında (yaş, cinsiyet, bireysel farkllıklar gibi) başarll olabileceği de dile getirilmiştir" (M29, syf:206), "Okul öncesi eğitim programı özel gereksinimli çocuklar için uyarlamalara yer vermektedir." (M20, syf:46) kısımlarında görüldüğü üzere okul öncesi eğitim programında özel eğitime önem verilmektedir. (M93, syf:26), (M140, syf:167), (M159, syf:35), (M164, syf:488), (M175, syf:1708), (M178, syf:86), (M196, syf:114) ve (M62, syf:483)'de bunu destekleyen nitelikte benzer cümleler yer almaktadır.

On beşinci tema olan programın rehberlik hizmetlerine hizmet etmesi incelendiğinde toplam 9 tane makalede konuyla ilgili cümlelerin yer aldığ 1 gözlemlenmiştir. "Okul öncesi öğretmenlerine okul öncesi eğitimde rehberlik hizmetleri ile ilgili eğitim verilmesi, rehber öğretmenlerin okul öncesi eğitime rehberlik desteği sunması ve okul öncesi öğretmenlerinin rehber öğretmenlerle işbirliği yapması durumunda okul öncesi eğitim programinin okul öncesi eğitimin amaç ve ilkelerine ilişkin ölçütlere tamamen ulaşmasına katkı sağlayabileceği düşünülmektedir." (M93, syf:26), "Okul öncesi eğitim programı rehberlik hizmetlerine önem 
vermektedir." (M90, syf:2232), "2013 programinda rehberlik hizmetlerine önem verilmektedir." (M91, syf:662), "Okul öncesi eğitimin amaçlarının gerçekleştirilmesi, okul öncesi dönemdeki çocuğa gerekli bilgi, beceri, tutum ve temel alışkanliklarm kazandırılması ve çocuklarm toplumun değer yargılarmı öğrenip uygulayabilmesi, iyi planlanmış eğitim programlar ve rehberlik hizmetleri ile sağlanabilir." (M81, syf:74), "MEB Okul Öncesi Eğitim Programmnn eklektik, sarmal olması ve rehberlik hizmetlerine önem vermesi onu diğer okul öncesi programlarnda ayrıştırmaktadır." (M23, syf:105) kısımlarında görüldüğü üzere okul öncesi eğitim programinda rehberlik hizmetlerine önem verilmektedir. (M98, syf:315), (M97, syf:383), (M24, syf:1090) ve (M20, syf:46) numaralı makalelerde de bu durumu destekleyen benzer cümleler yer almaktadır.

Araştırmanın üçüncü alt amac1 "Okul Öncesi Eğitim Programının içerdiği ölçütlere ulaşma ve ulaşamama sebepleri nelerdir?" şeklinde ifade edilmiştir. Tema ve kodlara ait bulgular Şekil 3'de verilmiştir.

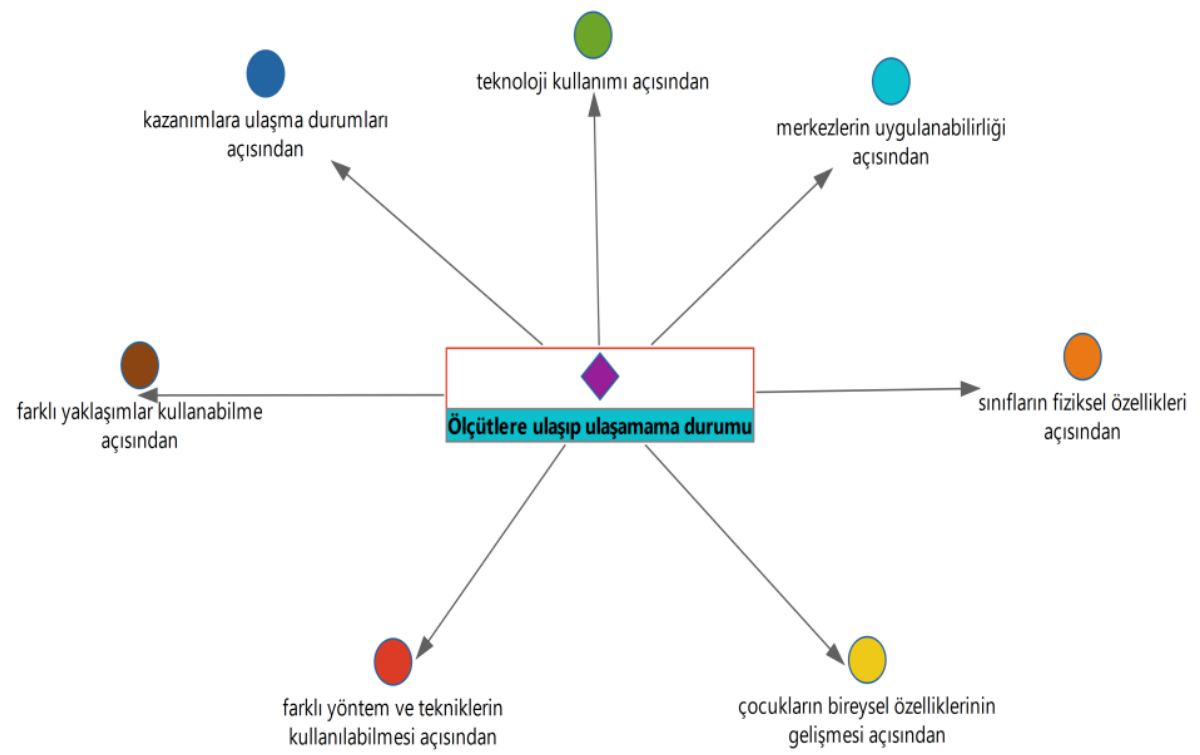

Şekil 3. Okul öncesi eğitim programının içerdiği ölçütlere ulaşma ve ulaşamama durumu

Şekil 3’de görüldüğü üzere okul öncesi eğitim programının içerdiği ölçütlere ulaşma ve ulaşamama durumu sınıfların fiziksel özellikleri, çocukların bireysel özelliklerinin gelişmesi için uygun ortam, teknoloji kullanımı, 
farklı yöntem ve tekniklerin kullanılabilmesi, merkezlerin uygulanabilirliği, farklı yaklaşımlar kullanabilme ve kazanımlara ulaşma durumları olmak üzere 7 tema altında toplanmıştır. Sınıfların fiziksel özellikler i incelendiğinde 4 adet makalede konu ile ilgili cümlelerin yer aldığ görülmüştür. “Okul öncesinin tüm yaşam boyunca süren etkisi düşünüldüğ̈̈nde, bu eğitimin kalitesini etkileyen bir faktör olarak okul öncesi smıflarnnn fiziksel özelliklerinin önemi de ortaya çıkmaktadır. Okul öncesinin tüm yaşam boyunca süren etkisi düşünüldüğünde, bu eğitimin kalitesini etkileyen bir faktör olarak okul öncesi sinuflarının fiziksel özelliklerinin önemi de ortaya çıkmaktadır." (M77, syf:48) cümleleri okul öncesi eğitim programının içerdiği ölçütlere ulaşmasında sınıfların fiziksel özelliklerinin önemini ortaya koymaktadır. (M156, syf:45), (M157, syf:227) ve (M160, syf:263) numaralı makalelerde benzer nitelikte cümlelerin yer aldığı görülmüştür.

İkinci alt tema olan çocukların bireysel özelliklerinin gelişmesi için uygun ortam incelendiğinde 1 adet makalede konu ile ilgili cümlelerin yer aldığ görülmüştür. "Gelişimin en hızh olduğu okul öncesi dönem içerisinde çocuklar gözlemleyerek ilgi, yetenek ve beceri düzeylerini belirlemek ve eğitim sürecinde buna dönük önlemler almak son derece önemlidir. çocuklarm diğer akranlarn ile birlikte olduklarn eğitim ortamlarmda bütün çocuklarm gelişimlerini en üst noktada gerçekleştirebilecekleri bireysel yetenek, ilgi ve becerilerini belirleyip buna göre uygun eğitim imkânları sunulması gerekmektedir." (M78, syf:900) cümlelerinde görüldügü üzere okul öncesi eğitim programının içerdiği ölçütlere ulaşmasında çocukların bireysel özelliklerinin gelişmesi için uygun ortam oluşturmak önemlidir.

Üçüncü alt tema olan teknoloji kullanımı incelendiğinde toplam 14 makalede konu ile ilgili cümlelerin geçtiği gözlemlenmiştir. "Kitap, tebeşir, kara tahta gibi geleneksel materyallerin kullanıldığı okullarda eğitimin daha çok eğitimci merkezli olduğu, fakat teknolojik materyallerin dahil edildiği simflarda eğitimin daha çok çocuk merkezli olduğu düşünülmektedir." (M79, syf:20), "Ülkemizde 2012 yllından itibaren okul öncesi, ilköğretim ve ortaöğretim düzeyindeki tüm okulları kapsayacak şekilde uygulanmaya başlanan FATiH Projesi ile bilgi ve iletişim teknolojilerinin eğitimde etkin olarak kullanılması amaçlanmıştır." (M83, syf:336) kısımlarında görüldü̆̆ü üzere okul öncesi eğitim programının içerdiği ölçütlere ulaşmasında teknoloji kullanımı önemli bir yer tutmaktadır. (M18, syf:397), (M32, syf:116), (M28, syf:98), (M30, syf:124), (M119, syf:565), (M133, syf:197), (135, syf:833), (M141， syf:123), (M151， syf:232), (M152, syf:161), 
(M163, syf:7) ve (M179, syf:2) numaralı makalelerde benzer nitelikte cümlelerin yer aldığg görülmüştür.

Dördüncü alt tema olan farklı yöntem ve tekniklerin kullanılabilmesi incelendiğinde toplam 3 makalede konu ile ilgili cümlelerin yer aldığı görülmüştür. "Okul öncesi dönemde, çocuklara uygun ortam sağlanması, gerçek hayata yakın oyunlar kurulması ve değişik yöntemlerin sinı ortamında yürütülmesi mümkündür." (M80, syf:24), "Okul öncesi dönemde sunulacak eğitimde rehber olarak alınan 2013 Okul Öncesi Eğitim Programı'nda farklı yöntem ve teknikler kullanılarak çocuklarm bildiklerini uygulamaları, yani aktif öğrenme yöntemlerinin kullanılması büyük önem taşımaktadır." (M83, syf:336) kısımlarına bakıldığında okul öncesi eğitim programının içerdiği ölçütlere ulaşmasında farklı yöntem ve tekniklerin kullanılmasının önemi görülmektedir. (M171, syf:45) numaralı makalede konu ile ilgili benzer nitelikte cümleler olduğu görülmüştür.

Beşinci alt tema olan merkezlerin uygulanabilirliği incelendiğinde toplam 2 makalede konu ile ilgili cümlelerin yer aldığı görülmektedir. "Yapılan araştırmalar fiziksel yapı ve öğrenci sayısı nedeniyle sınflarda öğrenme merkezleri oluşturmakta sorun yaşandığıı, uygun zamanda yeterli hizmet içi eğitim să̆lanmadığın, ancak programa ve yapılan yeniliklere yönelik olumlu tutum sergilendiğini saptamıştır." (M82, syf:161), "Çocuklar merkezlere ulaşmada sorun yaşarlarsa, sorun yaşamadikları merkeze yönelme olasılıkları artabilir. Böylece ulaşamadıkları merkezdeki öğrenme firsatlarından uzaklaşmış olabilirler. Bununla birlikte çocuklarm okul öncesi eğitimden en uygun şekilde yararlanabilmelerinin, ihtiyaç duydukları her şeye ulaşabilmeleri, kendilerini rahat ifade edebilmeleri, yaratıcı düşünebilmeleri ve çeore hakkında merak duyabilmelerine bağh olduğu belirtilmektedir." (M81, syf:94) kısımlarında okul öncesi eğitim programının içerdiği ölçütlere ulaşmasında merkezlerin uygulanabilirliğinin ve bu konuda bilgilendirilmenin önemi görülmektedir.

Altınc alt tema olan farklı yaklaşımlar kullanabilme incelendiğinde 1 makalede konu ile ilgili cümlelerin yer aldığı görülmektedir. “Öğrenenin merkeze alınmasi ve teknolojik gelişmelerin de etkisi ile yeni materyaller, yeni yöntemler ve yeni yaklaşımlar geliştirilmiş, ayrıca geliştirilmeye de devam etmektedir." (M84, syf:431) cümlesi okul öncesi eğitim programının içerdiği ölçütlere ulaşmasında farklı yaklaşımlar kullanıldığını göstermektedir.

Yedinci alt tema olan kazanımlara ulaşma durumu incelendiğinde 1 adet makalede konu ile ilgili cümlelerin yer aldığı görülmüştür. "Programda çocukların dâhil olduğu tek değerlendirme uygulamast ise yapılan etkinliklerin etkinlik 
sonrasinda öğrencilerle değerlendirilmesidir. Burada öğretmenden beklenen betimleyici, duyuşsal, kazanımlara ilişkin ve yaşamla ilişkilendirmeye yönelik sorularla etkinliklerin uygulama sonrası öğrencilerle değerlendirilmesidir." (M85, syf:239) cümlelerinde görüldüğü üzere okul öncesi eğitim programının içerdiği ölçütlere ulaşmasında kazanımlara ulaşma durumunun değerlendirmesi yapilmaktadır.

Araştırmanın dördüncü alt amacı "Okul Öncesi Ĕ̆itim Programları uygulanırken yaşanan sorunlar nelerdir?" şeklinde ifade edilmiştir. Tema ve kodlara ait bulgular Şekil 4'de gösterilmiştir.

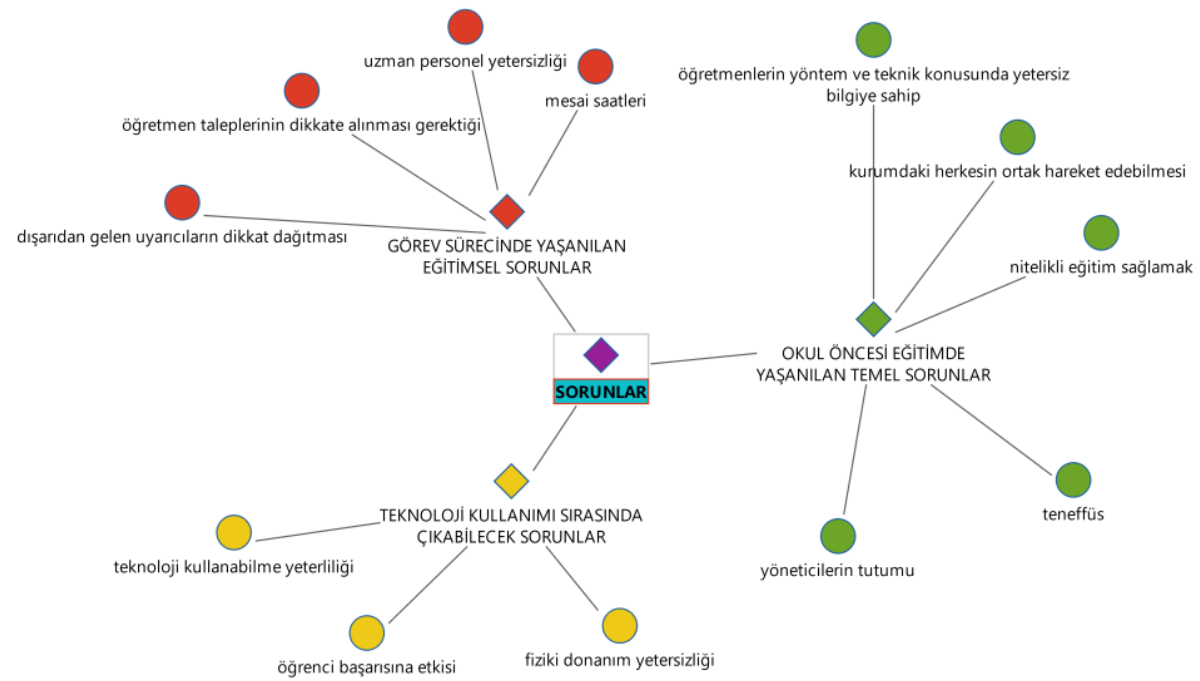

Şekil 4. Okul öncesi eğitim programları uygulanırken yaşanan sorunlar

Şekil 4'de görüldüğü üzere okul öncesi eğitim programlarının düzenlenmesi okul öncesi eğitimde yaşanılan temel sorunlar, teknoloji kullanımı sırasında çıkabilecek sorunlar ve görev sürecinde yaşanılan eğitimsel sorunlar olmak üzere 3 tema altında toplanmıştır. Okul öncesi eğitimde yaşanılan temel sorunlar başlı̆̆ incelendiğinde toplam 7 makalede konu ile ilgili cümlelerin yer aldığı görülmüsstür. “Öğretmenlere göre, rehberlik ve denetim sistemindeki yetersizlikler, öğretmenlerin teneffüs sürelerinin olmaması, ikili eğitim uygulaması, personel yetersizliği ve mevzuat yetersizliği okul öncesi eğitimdeki temel sorunlar arasindadır." (M51, syf:483) ve yine ayn makalede bulunan "Okul öncesi eğitim alında yaşanan temel sorunlarm belirlenmesi ve sorunlara yönelik çözüm önerileri geliştirilmesi, yaygınlaşma sürecinde altyapı ihtiyaçlarmın 
belirlenerek iyileştirmeye gidilmesi, sürecin verimli bir şekilde yürütülmesi ve nitelikli bir eğitim verilebilmesi açısından son derece önemlidir." (syf:486), "Süreçte ögretmenler, sosyal ve duygusal sorunlarn sinfta etkili biçimde çözemedikleri takdirde çocukların uyum davranışları zayıflamakta, sınıf içerisinde yürütülmekte olan eğitim süreci de sekteye uğramaktadır." (M52, syf:89), "Okul öncesi eğitim programı hakkında yapılan araştırmalar incelendiğinde öğretmenlerin yoğun olarak fiziksel ortam ve eğitimin değerlendirilmesi konusunda sorunlar yaşadıkları belirtilmiştir." (M54, syf:69), "okul öncesi öğretmenlerinin iş verimlerinde niteliğin arttırlması; çalışma koşullarmm düzenlenmesine ve sorunlarmm ortaya koyulup etkili bir şekilde çözülmesine bağhldır." (M55, syf:72) kısımlarında görüldüğü üzere okul öncesi eğitim programında temel sorunlar tespit edilmekte ve çözüm önerileri üretilmektedir. (M53, syf: 162), (M158, syf:8) ve (M72, syf:29) numaralı makalelerde de konuyu destekleyen nitelikte benzer cümleler yer almaktadır.

İkinci alt tema olan teknoloji kullanımı sırasında çıkabilecek sorunlar incelendiğinde toplam 3 makalede konu ile ilgili cümlelerin yer aldığ görülmüştür. “Öğretmenlerin teknoloji kullanımına yönelik bakış açılarının olumlu olduğu ancak matematik uygulamalar sirasinda teknolojiden yeterince yararlanamadıkları, öğretmen merkezli yöntemlere ağırlık verdikleri ortaya çıkmıştır." (M18, syf:413), "Çocuklarm birçoğu uyuma ihtiyacı dışında kalan bütün etkinliklerden çok teknolojiyle zaman geçirmektedir. Öğretmenler bu durumu avantaja dönüştürerek etkinlik saatlerinde kullandıklar materyallere teknolojizi dahil ettiklerinde çocuklar üst düzeyde güdülenecek ve yapılan etkinliğe aktif olarak katılmak isteyecektir Böylece etkinlik saatlerinde kullanılan teknoloji öğrenci başarısın olumlu yönde etkileyecektir. Aynı zamanda öğretmen, etkinlik saatlerinde teknolojik materyaller kullanarak teknolojizi bilinçsiz şekilde kullanan okul öncesi çocuklarında teknolojiyi iyi yönde kullanma bilincini oluşturabilecektir." (M70, syf:87) kısımlarında görüldüğü üzere okul öncesi eğitim programında teknoloji kullanımı önemlidir ve kullanımdaki eksiklikler saptanmaya çalışılmaktadır. (M51, syf:498) numaralı makalede de konuyu destekleyen nitelikte benzer cümleler yer almaktadır.

Üçüncü alt tema olan görev sürecinde yaşanılan eğitimsel sorunlar incelendiğinde 3 adet makalede konu ile ilgili cümlelerin yer aldığ1 görülmüştür. "Temel öğelerinin insan olmasından dolayı eğitim kurumlarından sorunlarm yaşanması doğal karşılanmahıdır. Ĕ̆itim kurumlarında, kişiler arası çatışma durumları, birey ile üstleri, birey ile astları ve birey ile meslektaşları (denk olan kişiler) 
arasında yaşanmaktadır." (M55, syf:72) cümlelerinde okul öncesi eğitim programı uygulanırken görev sırasında yaşanılan sorunlar görülmektedir. (M161, syf:77) ve (M199, syf:71) numaralı makalelerde konu ile ilgili benzer nitelikte cümleler yer almaktadır.

\section{Tartışma, Sonuç ve Öneriler}

Okul Öncesi Eğitim Programı İle İlgili Dergipark'ta Yayımlanan Makalelerin İncelenmesi (2013-2020) konulu çalışmada toplam 201 makale üzerinde inceleme yapılmış olup 4 tane alt amaç oluşturulmuştur. Bu alt başlıklar en çok içerdikleri konular dikkate alınarak kendi aralarında gruplara ayrılmıştır. Birinci alt amaç olan okul öncesi eğitime etki eden okul dışı faktörler arasında en etkili olan faktörün aile olduğu görülmüştür. Aktaş ve Arnas (2011) yaptıkları araştırmalarda aile katılımının okul öncesi başarıya olan katkısından bahsederlerken Hamamcı ve Akyol (2003) çalışmalarında çocukların aileyi rol model alarak ve onları taklit ederek hayatı ögrendiklerini savunmuşlardır. Gürşimşek' in (2003) yaptığı bir araştırmada öğretmen okul aile işbirliğinin önemli bir ögesi ve aile katılımı çalışmaları ile okul aile işbirliğini en iyi şekilde organize eden kişi olarak açıklanmıştır. Bozyiğit (2013), ailelerin tutumlarının çocukların gelişimi üzerindeki etkilerinden bahsetmiştir. Küçüktüran, Altun ve Akbaba-Altun (2013) çalışmalarında ailelerin çocukları okul öncesi eğitime teşvik edecek ve bilinçlendirecek kişiler olduklarını söylerken, Ok (2016) yaptığı çalışmada ailenin eğitim kalitesini en üst seviyeye çıkarmakta önemli bir etken olduğunu dile getirmiştir.

Okul öncesi eğitime etki eden okul dışı faktörlerden en çok bahsedilen bir diğer faktörün çevre olduğu görülmüştür. Kıldan (2012), Oğuzkan ve Oral (1992), Unutkan (2007) ve Ünal (2013) yaptıkları çalışmalarda çocuğun okul öncesi dönemde çevresel uyarıcılara çok açık olduğunu ve olumlu veya olumsuz denebilecek bütün davranışları çok hızlı bir şekilde kazandıkların ifade etmişlerdir. MEB (2013)'te çevre etkisi çocukların keşfetme becerisi üzerine katkısı ve neleri hangi hızla öğreneceklerine olan etkisi çerçevesinde anlatılmıştır. Çevre etkisini aileler açısından inceleyen Aktaş ve Arnas'a (2002) göre çocuğunu okul öncesi kurumlara gönderecek olan bireyler edinmek istedikleri bilgileri yakın çevrelerinden, arkadaşlarından ve başka ailelerden edinirler. Ayrıca velilerin başarı algısı üzerinde çevrenin etkili olduğu Ok (2016) tarafından yapılan çalışmada da ortaya çıkarılmıştır. Hals- 
tead ve Taylor (2000), değerler eğitiminin çocuklara aktarılmasında çevre etkisinden bahsetmişlerdir.

Okul öncesi eğitime etki eden okul dışı faktörlerin üçüncüsü olan teknoloji faktörü üzerine yapılan araştırmalara bakıldığında Bağcı ve İvrendi (2016) okul öncesi eğitimde matematik kullanımı sırasında teknolojiden yararlanma durumunu incelerken, Uyanık-Balat (2011), okul öncesi eğitimde fen eğitimi sırasında teknoloji kullanarak bilimsel okur yazarlığı kazandırılması konusunu ele almışlardır. Bu çalışmalara benzer çalışmalar olarak Hacısalihoğlu-Karadeniz (2014) ve Kayhan ve Kılıç (2014) çalışmalar yapmış olup matematik ve fen etkinliklerinde teknoloji kullanımı üzerine bilgiler vermişlerdir. Alan yazın incelendiğinde okul öncesinde teknoloji kullanımı anlamında matematik ve fen etkinlikleri dışında bir boyutun ele alınmadığı ve bu doğrultudaki çalışmalarda eksiklik olduğu görülmüştür.

İkinci alt amaç olan okul öncesi eğitim programının özellikleri incelendiğinde ilk olarak çocuk merkezi olması ile ilgili çalışmaların daha çok olduğu gözlemlenmiş̧ir. Çocuk merkezli eğitim programları üzerine çalışma yapan Demirel (2011), çocukların etkili bir öğrenme gerçekleştirebilmeleri için yapılan etkinliklere etkin katılım sağlamaları gerektiğini dile getirirken Gordon ve Browne (2007), her çocuğun ayrı ayrı çok özel olduğunu ve hazırlanan etkinliklerin onların bireysel özelliklerine göre planlanması gerektiğini ifade etmişlerdir. Çocuğun kendi yararına olan etkinlikleri seçme ve aktif olarak katılmasına olanak sağlayan katılım hakkı üzerine çalışmalar yapan Gürkan (2013), katılım hakkının somut bir duruma getirilmesini ve çocuğun özgürleştirilebilmesini çocuk merkezli programların uygulanmasına bağlamıştır.

Okul öncesi eğitim programının bir diğer özelliği esnek yapıda olmasıdır (MEB,2013). Başaran ve Ulubey'in (2018), etkinlikler hakkında öğretmen görüşleri alarak yaptıkları çalışmalarında öğretmenlerin birçoğunun programın esnek olmasının etkinlikleri uygulamada kolaylık sağladığını ifade etmişlerdir. Demirel (2005), okul öncesi dönemin temel becerilerine ulaşmayı kolaylaştıran ve yeterlilikleri geliştirebilen esnek bir programa ihtiyaç duyulduğunu ifade ederken, Özsırkıntı vd. (2014), esnek programların öğrencilerin yaparak yaşayarak öğrenmesine fırsat tanıdığını belirtmişlerdir.

Bir diğer özellik ise programın sarmal olmasıdır (MEB, 2013). Okul öncesi eğitim programı hakkında öğretmen görüşleri alarak çalışan Köksal, Balaban Dağal ve Duman'ın (2016) çalışmalarında öğretmenlerin sürenin ye- 
tersiz gelmesi nedeniyle yetiştiremedikleri etkinlikleri programin sarmal özelliği sayesinde başka etkinliklerde telafi edebildiklerini belirtmişlerdir.

Okul öncesi eğitim programının özellikleri arasında eklektik olması da bulunmaktadır (MEB, 2013). Gülçiçek, Tonga ve Tantekin Erden (2019), programin farklı yaklaşımlardan etkilenerek oluşturulduğunu ifade ederken, Zembat, Günşen ve Gök Çolak (2019) yaptıkları çalışmada öğretmenlerin planın birçok kazanımı içerdiği için eklektik olduğunu söylediklerini ama bu kazanımları tam olarak ifade edemediklerini dile getirmişlerdir.

Okul öncesi eğitim programı çocukların tüm gelişim alanlarını desteklenmesi açısından dengeli hazırlanmıştır (MEB, 2013). Bu programın çocukların gelişim özelliklerini gözettiği ve desteklediği Alak ve Alabay (2017), Başaran ve Ulubey (2018), Göle ve Temel (2015), Gülçiçek, Tonga ve Tantekin Erden (2019), Koçyiğit (2014) ve Köksal, Balaban Dağal ve Duman'ın (2016) çalışmalarında da yer almaktadır.

Okul öncesi eğitim programı oyun temelli olması gözetilerek hazırlanmıştır. Başaran ve Ulubey (2018), yaptıkları çalışma sonucunda öğretmenlerin birçoğunun uyguladıkları etkinliklerde yöntem ve teknik olarak oyunu tercih ettiklerini söylemişlerdir. Özyürek, Özkan, Begde ve Yavuz (2015) oyun çocuğun hayatında çok önemli bir yer tuttuğu için oyun temelli okul öncesi eğitim programı hazırlanması gerektiğini söylemişlerdir. Çocukların birçok sosyal beceriyi kazandığı okul öncesi dönem üzerine araştırma yapan Aksoy'da (2014), araştırmasında oyun temelli yöntem kullanıldığı takdirde kendini kontrol etme, atılganlık boyutundaki sosyal beceriler davranışlar üzerinde önemli gelişmeler olabileceğini ifade etmiştir.

Okul öncesi eğitim programının bir diğer özelliği de keşfederek öğrenmeyi ön planda tutmasıdır (MEB, 2013). NAEYC ve NAECS/SDE (2003), programın çocuğun her bilgiyi keşfetmesine uygun ortam hazırladığını ve yetersizlik durumlarına da uygun olarak seçildiğini dile getirerek ayn görüşü belirtmişlerdir. Gürkan ve Koran (2014), yaptıkları araştırmada programın keşfederek öğrenme üzerine hazırlanmasının çocuğun katılım hakk1na yer verdiğini ve özgür bir ortamda öğrenmesi için firsat tanınmasına katkısı olduğunu söylemişlerdir.

Okul öncesi eğitim programının özelliklerinden birisi yaratıcılıktır MEB (2013). Köksal, Balaban Dağal ve Duman (2016), okul öncesi ve ilkokul programları üzerine çalışma yürütmüş olup çalışmalarında her iki programda da yaratıcılık kavramının ele alındığını ve önemli bir yeri olduğunu 
ifade etmişlerdir. Feeney ve Moravick (1987), çocukların yaratıcılık ve estetik duygularının erken yaşlarda destek görmediği takdirde ilerleyen yıllarda üretken bireyler olmalarına engel olabileceğini söylemişlerdir.

Okul öncesi eğitim programının bir diğer özelliği günlük yaşam ve yakın çevre ile ilişkili olarak hazırlanmış olmasıdır (MEB, 2013). Programın günlük yaşamdaki semboller ile ilişkili olduğu Başaran ve Ulubey (2018) tarafından yapılan çalışmada da ortaya çıkarılmıştır. Öte yandan etkinliklerde kullanılan kitap ve çalışma kağıtlarının günlük yaşam ile ilgili olduğu (Alak ve Alabay, 2013), öz bakım becerileri ile ilgili kazanımlar arasında günlük yaşam becerileri için gerekli araç gereç kullanımının yer aldığı (Güldalı ve Demirbaş, 2017) aşikardır.

Okul öncesi eğitim programında temalar amaç değil araçtır (MEB, 2013). Bu doğrultuda Tuncer (2015), çağdaş yaklaşımların tema ve konularının okul öncesi eğitim programı ile benzer olduğunu söylemiştir.

Okul öncesi eğitim programı kültürel ve evrensel değerlere önem vermektedir (MEB, 2013). Gürkan (2012), okul öncesi eğitim programı ile sosyokültürel dinamizme uygun, nitelikli insan gücünün yetiştirilebileceğini ifade etmiştir. Okul öncesi dönem eğitimi, toplumun kültürel değerleri ve özellikleri doğrultusunda çocuğu yönlendiren en kritik süreçtir (Kandır, 1999; Öktem, 1986; Poyraz, 2003; Turaşl1, 2007).

MEB (2013), aile katılımın programın temel özelliklerinden biri olarak benimsemektedir. Zembat ve Unutkan (2001), ailenin eğitim sürecine dahil edilmesi gerektiğini ifade etmiştir. Okul öncesinde aile katılımı Cömert ve Erdem'in (2011) çalışmalarında aile eğitim etkinlikleri, aile iletişim etkinlikleri, ailelerin eğitim etkinliklerine katılımı, ev ziyaretleri ve evde yapılabilecek etkinlikler, bireysel görüşmeler, toplantılar, yönetim ve karar verme süreçlerine katılım gibi çeşitli şekillerde açıklanmıştır. Değerlendirme boyutunda da aile katılımının yeri olduğu Sapsağlam (2013) tarafından belirtilmiştir.

Okul öncesi eğitim programının temel özelliklerinden biri olan değerlendirme çok yönlü ve öğretmen tarafından yürütülen önemli bir süreçtir (MEB, 2013; Fetihi, 1998; Senemoğlu, 1994). Gürkan ve Koran (2014), değerlendirme sürecinin çocuğun katılım hakkını yansıttığını belirtmişlerdir. Lewy (1977) program değerlendirmenin programı geliştirmek ve daha kolay kararlar alınmasını sağlamak için önemli bir unsur olduğunu söylerken, 
Akınoğlu (2005), Bilasa (2006) Demirel (2003), Cömert (2004) değerlendirmelerin eğitim programlarının niteliğini artırdığını ifade etmişlerdir.

Okul öncesi eğitim programının bir diğer özelliği özel eğitime önem veriyor olmasıdır ve programda ilk kez özel eğitimli çocuklar için uyarlama kısmı yer almış, özel düzenlemeler yapılmasına özen gösterilmiştir (MEB, 2013). Okul öncesinde yapılan değerlendirmeler özel eğitimli öğrencilerin saptanmasında önemli rol oynarken okul öncesi öğretmenlerinin ve rehber öğretmenlerin özel eğitim öğrencilerini saptama ve onlara rehberlik etme konusunda yetersiz kalabildikleri durumlar olabilmektedir (Başaran ve Ulubey, 2018). Deniz (2001) yaptığı çalışmada bu kararlara uyma konusunda sıkıntılar olduğunu ve istenilen hedeflere tam olarak ulaşılamadığını ifade etmiştir. Çocukların sosyal kabul görmesini kolaylaştıran kaynaştırma eğitimi sayesinde, çocuklar ilerideki hayatlarında daha başarılı olmaktadırlar (Batu ve Yükselen, 2014). Kaynaştırma eğitiminin başarıya ulaşmasının şartı, çocuğun aktif olarak sürece katılmasıdır (UNESCO, 1994).

Okul öncesi eğitim programı rehberlik hizmetlerine önem vermektedir (MEB, 2013). Çalışandemir'de (2014) yaptığı çalışmada rehberlik hizmetlerinin program için önemli bir öge olduğunu söyleyerek planın özelliğini aktarmıştır. Temel, Kandır, Erdemir ve Koçer-Çiftçibaşı (2005), okul öncesi eğitimin amaçlarına doğru şekilde ulaşabilmesinin rehberlik hizmetleri ile sağlandığını söylerken Gülçiçek, Tonga ve Tantekin Erden (2019) yayımlanan son okul öncesi programı olan 2013 yılı programının diğer yıllardaki programlardan farklı olma sebeplerinden biri olarak rehberlik hizmetlerine önem vermesini göstermişlerdir.

Üçüncü alt amaç olan okul öncesi eğitim programının ölçütlere ulaşma ve ulaşamama sebepleri incelendiğinde ilk olarak sınıfların fiziksel özellikleri gözlemlenmiştir. Ayyıldız ve Kahraman (2019) yaptıkları araştırma sonucunda okul öncesi sınfflarında genellikle materyal eksikliği olduğunu, var olan materyallerin de yetersiz kalabildiğini belirtmiştir. Kıldan (2010) ise sadece sınıfın etkili olmadığını, okul dışının düzenlenmesinin de eğitim ortamlarına büyük etkisi olduğunu söylemiştir. Canbeldek ve Işıkoğlu Erdoğan (2017), sınıfta bulunan çocuk sayısının eğitime olan etkisi üzerine araştırma yapmış ve kalabalık gruplar ile daha az sayıda öğrenci bulunan sinıflardaki eğitim durumunda büyük farklllıklar olduğunu söylemişlerdir.

Okul öncesi eğitim programının ölçütlere ulaşmasında önemli bir etken çocukların bireysel özelliklerinin dikkate alınmasıdır. Dağlığlu, Turupcu 
Doğan ve Basit (2017) yaptıkları araştırma sonucunda Türkiye'deki öğretmenlerin öğrencilerin bireysel özelliklerine dikkat ederek çalışmalar yapma konusunda yeterince duyarlı olmadıklarını, bunun en çok gözüktüğü alanın da özel eğitimli öğrenciler üzerinde olduğunu ifade etmişlerdir.

Okul öncesi eğitim programının ölçütlere ulaşmasında bir etken olarak teknoloji kullanımı da gösterilmektedir. Teknolojik gelişmeler nedeniyle çocukların günlük hayatlarında teknolojiyi kullanmaları kaçınılmaz hale gelmiş ve bu nedenle de bilgisayarların eğitim materyalleri olarak kullanılması artmıştır (Önal ve Keleş, 2012; Miller, 2005; Ulu ve Baş, 2020). Ergüleç ve Kiremit (2019), teknolojik gelişmeler sonucunda ülkemizde gerçekleştirilen FATİH projesini anlatmışlar ve projenin başarılı ilerleme gösterdiğini söylemişlerdir. Bağcı ve İvrendi (2016), öğretmenlerin matematik derslerindeki teknoloji kullanımlarını araştırmış ve teknolojiye olumlu baktıkları halde kullanma konusunda yetersiz kaldıklarını söylemiştir. Kardeş (2020), teknolojinin olumsuz yönlerine de değinerek çocukların teknolojiden yararlanma ve sosyal medya kullanımı sırasında öğretmen denetimi altında olmaları gerektiğini belirtmiştir.

Okul öncesi eğitim programının ölçütlere ulaşmasında farklı yöntem ve tekniklerin kullanılması da önemli bir etken olarak görülmektedir. Kaya, Günay ve Aydın (2015), okul öncesi dönemde farklı yöntem ve tekniklerin kullanılmasının önemli olduğunu söylemiş ve bu çalışmalarında hikaye ve drama tekniklerinin sık kullanılan yöntemler olduğu üzerine araştırma yapmışlardır. Yalçın ve Uzun (2018), öğretmenlerin ders başarısını artırmak ve hedeflediği kazanımlara ulaşabilmesi için çocuklara uygun yöntem ve teknikleri seçmeleri gerektiğini ifade etmişlerdir.

Okul öncesi eğitim programının ölçütlere ulaşmasını kolaylaştıran bir diğer belirleyici merkezlerin uygulanabilirliğidir. Gülay Ögelman ve Karakuzu (2016), yaptıkları araştırma sonucunda sınıflarda en çok bulunan merkezin dramatik oyun merkezi olduğunu bunu da fen, blok ve kitap merkezinin takip ettiğini söylemişlerdir. Özkubat (2013) çocuklar bir merkeze ulaşmada sorun yaşarlarsa diğer merkezlere ulaşma olasılıklarının artacağını söylemiştir. Vogel (2012), merkezlerde resim ve yazı kullanmanın öğrenmeyi çok desteklediği yönünde çalışmalar yaparak görseller ile desteklenen merkezlerin daha kalıcı öğrenmelere yol açtı̆̆ını belirtmiştir.

Okul öncesi eğitim programının ölçütlere ulaşmasını etkileyen etmenler arasında farklı yaklaşımları kullanabilmek de önemli bir etkendir. Çelik ve 
Buluç (2016), eski zamanlardan kalan öğrenci pasifliğini yıkarak öğrenciyi aktif kılan bilişsel yaklaşım üzerine çalışmalar yürütürken, Yıldız Demirtaş (2015) aktif öğrenme yaklaşımının sosyal becerilere olan etkisi üzerine çalışmalar yürütmüştür. Torun Yeterge, Yıldız Demirtaş, Coşkun ve Vardarcı Kaçar (2019), aktif öğrenme yaklaşımının bütün öğretmenlere ve öğretmen adaylarına hizmet içi eğitim kapsamında sunulması gerektiğini söylemişlerdir.

Okul öncesi eğitim programı ölçütlere ulaşırken hedeflenen kazanımlara ulaşma durumunu da dikkate almıştır. Programdaki kazanımlar çok yönlü değerlendirmeyi içermelidir (MEB, 2013). Okul öncesi eğitim programı kazanımlarının ayrıntılı ve profesyonel olarak değerlendirilmesinde eksiklikler olduğu yapılan çalışmalar sonucunda ortaya çıkmıştır (Durmuş̧̧elebi ve Akkaya, 2011; Özsırkıntı, Akay ve Bolat, 2014).

Dördüncü alt amaç olan okul öncesi eğitim programı uygulanırken yaşanan sorunlar ve bu sorunların nasıl düzeltilebileceği konusunda temel sorunlar ele alınmıştır. İncelenen çalışmalarda değinilen en önemli sorunlardan birisi yöneticilerin sınıflara ilgisiz kalmasıdır (Ardıç,2011). Bu soruna istinaden Can ve Bayramoğlu(2016), alınan kararlara yöneticilerin öğretmenleri de dahil etmesi durumunda yaşanan sorunların daha aza indirgenebileceğini belirtmişlerdir. Diğer bir sorun olarak okul öncesinde teneffüs olmaması ortaya çıkmıştır. Bu sorun hem fiziksel ihtiyaçları karşılamak anlamında hem de meslektaşlar ile sosyalleşmeyi engellemesi açısından çalışmalarda ele alınmıştır (örn. Can ve Serençelik, 2017; Sabancı, Altun ve Uçar Altun, 2018; Tok, 2002). Öğretmenlerin sınıf içindeki problemleri çözme konusunda yeterli derecede yöntem ve strateji bilmemeleri diğer bir sorun olarak ele alınmıştır (Beyazkürk ve Kesner, 2005; Bursalığlu, 2008; Zembat, 2012). Bu kapsamda sorunların çözümü için önce sorunun kaynağının bulunmasının ve eğitim kurumundaki herkesin ortak hareket edebilmesinin önemli olduğu vurgulanmıştır(Bursalığlu, 2008; Zembat, 2012).

Okul öncesi eğitim programının teknoloji alanında da sorun yaşayabileceği düşünülmüş ve araştırmalar yapılmıştır. Sınıflarda teknolojik donanımın bulunmaması ve öğretmenlerin bu eksikliği gidermekte zorlanmaları en çok karşılaşılan sorunlardan biridir (Can ve Kılıç, 2019). Diğer bir teknolojik sorun olarak öğretmenlerin teknolojiyi kullanma yeteneklerinin sınırlı olması ortaya çıkmıştır. Bu sorun doğrultusunda yeterli düzeyde teknoloji bilgisine sahip olmayan öğretmenlerin sinıflarda uygulama konusunda 
eksik kalabilmeleri çalışmalara konu olmuştur (Bağcı ve İvrendi, 2016; Usta ve Korkmaz, 2010). Teknolojinin düzgün bir şekilde kullanılabildiği etkinliklerde öğrenci başarısı arttığı vurgulanmıştır (Kuzgun ve Özdinç, 2017).

Okul öncesi eğitim programının sorun yaşayabileceği düşünülen konular arasında görev sürecinde yaşanan eğitimsel sorunlar yer almaktadır. Dışarıdan gelen uyarıcılar ortam dikkatli bir şekilde düzenlenmediyse çocukların dikkatini kolay bir şekilde dağıtabilmektedir (Bartan, 2018). Aynı zamanda, mesai saatlerinin iyi düzenlenmemiş olması ve uzman personel konusunda yaşanan yetersizlikler de çalışma ortamında sorunlar çıkmasına yol açabilmektedir (Tok, 2002). Fiziksel alt yapı nedeniyle yaşanan sorunlar da sıklıkla görülmektedir fakat öğretmenlerin talepleri dikkate alındığı takdirde ve bütün okul bir araya gelerek sorunların çözülmesi için uğraşttğında bu sorunların daha kısa sürede ortadan kalkacağı ifade edilmiştir (Dikici Sığırtmaç vd., 2011; Okutan, 2003).

İlgili alan yazın incelendiğinde yapılan çalışmalara bakılarak bazı sonuçlara ulaşmak mümkündür. Okul öncesi eğitime okul dışı etmenler olarak bilinen aile, çevre ve teknolojinin büyük etki ettiği görülmektedir. Aynı zamanda okul öncesi eğitim programının hedeflediği kazanımlara ulaşması için çocukların bireysel özelliklerine dikkat edilmesi gerektiği tespit edilmiştir. Sınıflarda yaşanan fiziksel donanım anlamındaki eksikliklerin eğitimi olumsuz etkilediği ve öğretmenlerin yaşadığı sorunlara çözüm bulmak için taleplerinin dikkate alınmasının önemli olduğu da sonuçlar arasında yer almaktadir.

Ulaşılan bulgu ve sonuçlar doğrultusunda şu önerilerde bulunmak mümkündür:

1. Aile katılımının bütün eğitim sürecine ciddi etkileri olması sebebiyle aileleri bu konuda bilgilendirmek ve sürece dahil olmak için daha istekli olmalarını sağlamak amacıyla çeşitli eğitimler verilebilir.

2. Teknolojinin etkinlikler ile olan ilişkisi incelendiğinde genellikle matematik ve fen etkinliklerinin teknoloji ile ilişkisinin incelendiği diğer etkinliklere yer veren çalışmaların eksik kaldığı gözlemlenmiştir. Okul öncesinde yer alan diğer etkinliklerin teknoloji ile ilişkisi üzerine daha fazla çalışmaya yer verilebilir.

3. Okul öncesi dönemi çocuklarının öğrenmesinde en etkili yöntemin oyun olarak görülmesi sebebiyle yapılan her etkinlikte oyuna daha fazla yer verilebilir. 
4. Okul öncesi dönem yaratııllı̆̆ın gelişmesi için kritik dönem olarak görüldüğünden bu yaş grubundaki çocuklar kurallara bağlllık yerine daha özgür bırakılabilir ve yaratıcllıklarına daha fazla destek olunabilir.

5. Değerlendirme sürecin nitelikli yürümesi ve gerekli durumlarda eksikliklerin düzeltilmesi için en önemli öge olarak görülmüş fakat öğretmenlerin değerlendirme yaparken çok yönlü değerlendirme konusunda eksiklikler yaşayabildikleri gözlemlenmiştir. Bu nedenle sürecin daha verimli ilerlemesi için öğretmenlere değerlendirme konusunda hizmet içi eğitimler sağlanabilir.

6. Özel eğitimli öğrencilere rehberlik etme konusunda ve kaynaştırma eğitime olan bakış anlamında sorunlar yaşandığı gözlemlenmiştir. Özel eğitim üzerine yalnızca öğretmenlerin değil, eğitim sürecine dahil olan idarecilere, öğrencilere, okul personeline ve velilere kadar herkese eğitici seminerler düzenlenebilir.

7. Çocuklara teknoloji eğitimi verilirken teknolojinin olumsuz yönlerinden korumak ve teknolojiyi sağlıklı kullanabilmelerine yardımcı olmak amacıyla medya okuryazarlığı eğitimlerine önem verilebilir.

8. Okul öncesi dönem çocuklarının araştırıcılık özelliklerinin geliştirilmesi üzerine alan yazında yeterli çalışma olmadığı görülmüştür. Bu anlamda çalışmalara yer verilebilir.

9. Okul öncesi sınıflarında fiziksel donanım anlamında eksikliklerin sık yaşandığ 1 ve bu eksikliğin öğretmenleri ve öğrencileri olumsuz etkilediği görülmüştür. Sınıfları fiziksel anlamda yeterli koşullara ulaştırabilmek için daha fazla çalışma yapılabilir. 


\title{
EXTENDED ABSTRACT
}

\section{An Examination of Articles Published in Dergipark Regarding Preschool Education Program}

\author{
Nazlı Sila Yerliyurt - Mustafa Ersoy \\ Sivas Cumhuriyet University
}

Education emerges from the moment human beings begin to learn and provides permanent learning by continuing throughout one's life(Aydin, 2006). Therefore, countries give more importance to education and allocate their resources more and more every day (Kale, 2010). The United Nations Convention on the Rights of the Child, adopted in 1959, provides education to ensure that children become a useful member of the society by protecting the rights of children in line with the basis of equality. The child has the right to grow up in a healthy way regardless of where he / she was born, therefore, pre-school education is seen as an important step that cannot be put at risk in the whole education system (Yllmaz, 2003).

Since pre-school education programs constitute the child's first learning experiences, necessity of a pre-school education program is an important element to carry out pre-school education systematically (Bertrand, 2012). In this sense, a pre-school education program should be prepared in a way that will support the developmental areas of the child and help manage the process properly (MoNE, 2013). Bertrand, 2012). Updating dates of preschool education programs in Turkey are listed as 1952, 1989, 1994, 2002, 2006 and 2013. The new preschool education program was put into practice in 2006, but it was revised in 2013 (MoNE, 2013).

This study aimed to examine a qualified preschool education program in more detail because it affects the whole life of the child, to determine the problems $\mathrm{s} / \mathrm{he}$ experiences and to make determinations that will be useful for the solution of these problems, and to shed light on the researchers in the following years by determining the missing issues in the literature. The sub-aims of the study are as follows:

1. What are the out-of-school factors affecting the Preschool Education Program? 
2. What are the features of Pre-School Education Programs?

3. What are the reasons for reaching and not reaching the criteria included in the Preschool Education Program?

4. What are the problems encountered while applying Pre-School Education Programs?

The content analysis method, one of the qualitative research methods, was used in order to examine the articles written in the field of preschool education between 2013-2020. The content analysis method consists of three headings: meta-analysis, meta-synthesis, and descriptive content (Çalık and Sözbilir, 2014). The content analysis is a technique that enables some parts of the text to be systematically summarized by dividing them into smaller content categories with coding (Büyüköztürk et al., 2008) and consists of organizing, classifying, comparing texts and drawing theoretical conclusions from texts (Cohen, Ma-nion, and Morrison, 2007). The study group of the study consisted of 201 articles, selected according to the criterion sampling method, on preschool education program and published in the last 7 years (2013-2020) within the scope of the program updated in 2013. The data were collected by scanning the relevant articles published between 2013-2020 in the Dergipark database. Themes and and codes were created with the content analysis through MAXQDA program. The emerging themes were "Out-of-school factors affecting the Preschool Education Program" "Features of pre-school education programs", "Reasons for reaching and not reaching the criteria included in the Preschool Education Program" and, "Problems encountered while applying pre-school education programs". The codes "family", "environment" and "technology" were took place under the first theme.

Some direct quotes regarding the first theme are as follows: "The involvement of the family in pre-school education contributes to the multifaceted development of the child. " (A1, p. 157), "The goals of pre-school education without family support cannot be expected to be fully achieved. It is difficult to achieve the desired quality in pre-school education without parental involvement. " (A2, p. 57), "No matter how high quality the education programs implemented in pre-school education institutions are, it is difficult to reach the desired goals unless they are supported 
by families." (A3, p. 28). When the environment theme was examined, it was observed that the effect of the environment on preschool education was observed in 25 articles. "The child is very sensitive to environmental stimuli in the preschool period. It quickly wins all behaviors that can be considered positive or negative. " (A3, p. 24), "How much children can discover, what they can learn, and how fast they can learn is closely related to how supportive their environment is and what opportunities are offered to them." (A6, p. 43), "In order for the child to grow up and develop positive attitudes towards learning, there is a need for an environment where qualified cognitive stimuli, rich language interactions, positive social and emotional experiences are offered to the child and the child's independence is supported. " (A7, p. 196). Regarding the theme "technology", it was seen that the effects of technology on preschool education program were mentioned in 12 articles. "Developments in the fields of mathematics, science and technology in the last century have increased the tendency of countries to these fields and have led them to focus more on science and mathematics education in their education policies. In this respect, considering that the early childhood years are magical years in which the foundations of many mathematical concepts are acquired, it is important to examine the mathematics skills of children of all age groups who have and do not receive preschool education (A18, p. 396-414).

Some codes taking part in the theme "Features of pre-school education programs" were being child-centered, flexible, spiral, eclectic, balanced, game-based, learning by discovering and developing creativity. For example, the quotation regarding the flexibility of the program is as follows: "This education program has been prepared as a child-centered and flexible program. However, it has not been evaluated whether the program includes children's rights in general and the child's right to participate in particular. " (A89, p. 206).

The codes physical characteristics of classrooms, suitable environment for the development of individual characteristics of children, the use of technology, the ability to use different methods and techniques, the applicability of the centers and, the ability to use different approaches took place under the theme of "Reasons for reaching and not reaching the criteria included in the Preschool Education Program." For 
example, the quotation Considering the effect of preschool throughout life, the importance of physical characteristics of preschool classrooms as a factor affecting the quality of this education becomes clear (A77, p. 48) reveals the importance of the physical properties of the classes in reaching the criteria included in the pre-school education program.

The problems regarding the last theme were aligned as "The main problems encountered in pre-school education", "the problems that may arise during the use of technology", and "the educational problems experienced during the task process." An article in the scope of the study mentions that "According to the teachers, the inadequacies in the guidance and supervision system, the lack of recess times for the teachers, dual education practice, lack of personnel and legislation are among the main problems in pre-school education" (A51, p. 483).

The results revealed that non-school factors had a great influence on preschool education, the program was prepared by considering the developmental characteristics of the children and a spiral relationship with educational programs of other courses, and teachers may have problems during the implementation phase due to physical inadequacies and lack of experience. While implementing the pre-school education program, it was suggested that in-service training programs for teachers should be organized, more studies on family education and developing the research skills of children should be carried out.

\section{Kaynakça / References}

Aktaş Arnas, Y. (2002). Okul öncesi dönemde matematik eğitimi. Adana: Nobel.

Aktaş Arnas, Y. (2011). Aile eğitimi ve okul öncesinde aile katılımı. Ankara: Vize Yayımcilik.

Aksoy, N. C. (2014). Dijital oyun tabanlı matematik öğretiminin ortaokul 6. sinıföğrencilerinin başarlarına, başarn güdüsü, öz-yeterlilik ve tutum özelliklerine etkisi. Yayımlanmamış Doktora Tezi. Ankara:Gazi Üniversitesi Eğitim Bilimleri Enstitüsü.

Alak, S.A. ve Alabay, E. (2017). Pamuk şekerim i-ii kitaplarının meb okul öncesi eğitim programı (2013) açısından değerlendirilmesi. Kastamonu Ĕ̆itim Dergisi, 25(6), 2229-2244. 
Alisinanoğlu, F. ve Kesicioğlu, O.S. (2010). Okul öncesi dönem çocuklarının davranış sorunlarının çeşitli değişkenler açısından incelenmesi: Giresun İli Örneği. Kuramsal Ĕ̆itimbilim, 3 (1), 93-110.

Aral, N.,Baran, G.,Bulut, Ş. ve Çimen, S.(2002), Çocuk gelişimi 1. İstanbul: Ya-Pa Yayımları.

Ardıç, Ü.Ü. (2011). Okul öncesi eğitiminde kalitenin geliştirilmesine ilişkin idareci, öğretmen ve veli görüşleri. Yüksek Lisans Tezi, Selçuk Üniversitesi, Sosyal Bilimler Enstitüsü.

Aslanargun, E. ve Tapan, F. (2011). Okul öncesi eğitim ve çocuklar üzerindeki etkileri. Abant İzzet Baysal Üniversitesi Eŏitim Fakültesi Dergisi, 11(2), 219-238.

Aydın, A. (2006). Eğitim ve öğretimde etik. Ankara: PegemA Yayımcllk.

Ayyıldız, E. ve Kahraman, E. (2019). Türkiye'de okul öncesi sınıflarının fiziksel özellikleri ve tasarımları üzerine yapılmış çalışmaların incelenmesi. Medeniyet Eğitim Araştırmalan Dergisi, 3(1), 47-60.

Bağcl, B. ve İvrendi, A. (2016). Türkiye' de okul öncesi dönem matematik becerileri ve eğitimi araştırmaları: Sentez çalışması. Necatibey Faculty of Education Electronic Journal of Science and Mathematics Education, 10(2), 391-425.

Bartan, M. (2018). Okul öncesi öğretmenlerinin etkinliklerde kullandıkları dikkat çekme ve dikkati sürdürme şekillerinin öğretmen görüşlerine göre incelenmesi. Bursa Uludağ Üniversitesi Eğitim Fakültesi Dergisi, 32 (1), 227244.

Bartan, M. ve Başal, H.A. (2018). Okul öncesi eğitimi öğretmenlerinin bilimsel süreç becerilerine ilişkin görüşleri ve sınuf içi uygulamaları. Abant İzzet Baysal Üniversitesi Ĕ̆itim Fakültesi Dergisi, 18(4), 1938-1959.

Başaran, S. T. ve Ulubey, Ö. (2018). 2013 okul öncesi eğitim programının değerlendirilmesi. Ankara Üniversitesi Eğitim Bilimleri Fakültesi Dergisi, 51(2), 1-38.

Batdı, V. (2019). Tam öğrenme modelinin çoklu bütüncül yaklaşımla analizi bağlamında türkçe öğretim programinda kullanilmasımın değerlendirilmesi. Yüksek Lisans Tezi. Kilis 7 Aralık Üniversitesi Lisansüstü Eğitim Enstitüsü Eğitim Bilimleri Anabilim Dalı, Kilis.

Batu, E.S. ve Yükselen, A. (2014). Her Yönüyle Okul Öncesi Eğitim 1. E, N. Metin, A. İ. Yükselen (Ed)., Erken Çocukluk Döneminde Kaynaştırma Uygulamalarn içinde (s.330 - 350), Ankara: Hedef Yayımları.

Bertrand J. (2012). Preschool programs: Effective curriculum. comments on kagan and kauerz and on schweinhart. In: Tremblay Re, Barr Rg, Peters Rdev, Eds. Encyclopedia On Early Childhood Development. Montreal, Quebec: Centre of Excellence for Early Childhood Development, 1-7. 
Beyazkürk, D. ve Kesner, J. E. (2005). Teacher-child relationships in Turkish and united states schools: A cross-cultural study. International Education Journal, $6(5), 547-554$.

Bilasa, P. (2006). NLP (Neuro linguistic programming) (Beyin dili programlamasi) pratisyenlik eğitim programının değerlendirilmesi. Yüksek Lisans Tezi, .Ankara Üniversitesi Eğitim Bilimleri Enstitüsü, Ankara.

Bildiren, A. (2018). Okul öncesi dönemde bilişsel yetenek ile problem çözme becerilerinin arasındaki ilişkinin incelenmesi. Milli Ĕ̆itim Dergisi, 47(1), 291-308.

Bozyiğit, S. (2013). Çocuklarm Çevre bilinçli tüketici olarak sosyalleşmesinde annelerin çocuk yetiştirme tutumlarmın rolü. Doktora tezi. Çukurova Üniversitesi Sosyal Bilimler Enstitüsü, Adana.

Bursalığlu, Z. (2008). Okul yönetiminde yeni yapı ve davranış. Ankara: Pegem Akademi Yayımları.

Can, E. ve Bayramoğlu, A. (2016). Ortaöğretimde okul yönetimine katılım. K.Beycioğlu, N.Özer, K.Koşar Ve İ.Şahin (Ed.), Eğitim Yönetimi Araştırmaları İçinde, (s.104-125), Ankara: Pegem Akademi.

Can, E. ve Kılıç, Ş. (2019). Okul öncesi eğitim: Temel sorunlar ve çözüm önerileri. Milli Eğitim Dergisi, 48(1), 483-519.

Can ve Serençelik (2017). Okul öncesi eğitim öğretmenlerinin okul yönetimine katılımlarının incelenmesi. Dicle Üniversitesi Ziya Gökalp Ĕ̈itim Fakültesi Dergisi, 30, 525-542.

Canbeldek, M. ve Işıkoğlu Erdoğan, N. (2017). The effects of early childhood classroom size and duration on development of children. Eurasian Journal of Educational Research (EJER ), 17(68), 257-271.

Coşkun, Y. ve Baş, A. (2015). Okul öncesi eğitime devam eden çocukların anne babalarının çocuk yetiştirmeye yönelik görüşlerinin karşılaştırılması. KSÜ Sosyal Bilimler Dergisi, 12(2). 195-210.

Cömert, S. (2004). Okulöncesi eğitim programı hakkında öğretmen görüşleri ve uygulamaları. Sakarya Üniversitesi Eğitim Fakültesi Dergisi, 7, 135-150.

Cömert, D. ve Erdem, E. (2011). Erken çocukluk döneminde aile katılım etkinlikleri. Ankara: Eğiten Kitap.

Çalışandemir, F. (2014). Oyunun önemi. yaşamın ilk yıllarında oyun: Oyuna çok yönlü bakış. Ankara: Pegem Akademi, 17-30.

Çelik, Ö. ve Buluç, B. (2016). Disiplinler arası yaklaşımla değer öğretiminde yaratıcı drama yönteminin kullanılması. Erzincan Üniversitesi Ĕ̆itim Fakültesi Dergisi, 20(1), 67-88. 
Dağll, A. (2007). Okul öncesi eğitimi alan ve almayan ilköğretim birinci smnf öğrencilerinin türkçe ve matematik derslerindeki akademik başarılarmm karşılaşttrılması. Yüksek Lisans Tezi. Selçuk Üniversitesi Sosyal Bilimler Enstitüsü Çocuk Gelişimi ve Ev Yönetimi Eğitimi Anabilim Dalı Çocuk Gelişimi Ve Eğitimi Bilim Dalı, Konya.

Dağlığlu, H.E., Turupcu Doğan, A. ve Basit, O. (2017). Kapsayıcı okul öncesi eğitim ortamlarında öğretmenler çocukların bireysel yeteneklerini belirlemek ve geliştirmek için neler yapıyor?. GEFAD / GUJGEF, 37(3), 883-910.

Demirel, Ö. (2005). Kuramdan uygulamaya eğitimde program geliştirme, Ankara: Pegem Yayımcilik.

Deniz, M. (2001). Milli Eğitim şuralarmm tarihçesi ve eğitim politikalarnna etkileri. Süleyman Demirel Üniversitesi Sosyal Bilimler Enstitüsü, Yüksek lisans Tezi.

Deniz, Ü. ve Yıldız, R. (2018). Milli Eğitim Bakanlığı okul öncesi eğitim programında cinsel gelişim ve cinsel eğitim. GEFAD / GUJGEF, 38(2), 431-447.

Dikici Sığırtmaç, A., Hoş, G. ve Abbak, B. S. (2011). Okul öncesi öğretmenlerinin kaynaştırma eğitiminde yaşanan sorunlara yönelik kullandıklanı çözüm yolları ve önerileri. Ahi Evran Üniversitesi Kırşehir Eğitim Fakültesi Dergisi, 12(4), 205-223.

Durmuşçelebi M. ve Akkaya D. (2011). 2006 okul öncesi eğitim programının uygulanmasının öğretmen görüşlerine göre değerlendirilmesi : Kayseri ili örneği. Erciyes Üniversitesi Sosyal Bilimler Enstitüsü Dergisi, 31, 255-272.

Düşek, G. ve Dönmez, B. (2012). Türkiye'de yayımlanan okul öncesi eğitim programlar. Mesleki Bilimler Dergisi, 1(1), 68-75.

Ekici, F. (2014). Aile özellikleri ile okul öncesi eğitime devam eden çocukların problem davranışları arasındaki ilişkinin incelenmesi. Akademik Sosyal Araştırmalar Dergisi, 2(2), 70-108.

Erbay, E. (2008). Okul öncesi eğitim alan ve almayan ilköğretim birinci sinıföğrencilerinin sosyal becerilere sahip olma düzeyleri. Yüksek Lisans Tezi. Pamukkale Üniversitesi Sosyal Bilimler Enstitüsü İlköğretim Ana Bilim Dalı Okul Öncesi Eğitimi Bilim Dalı, Pamukkale.

Ergüleç, F. ve Kiremit, R. F. (2019). Tablet bilgisayarların okul öncesi dönemde resim çiziminde kullanılması. Eğitimde Kuram ve Uygulama, 15(1), 17-36.

Erkan, S. ve Kırca, A. (2010). Okul öncesi eğitimin ilköğretim birinci sınıf öğrencilerinin okula hazır bulunuşluklarına etkisinin incelenmesi. Hacettepe Üniversitesi Ĕgitim Fakültesi Dergisi, 38(38), 94-106. 
Erşan, Ş. (2019). Ebeveynlerin okul öncesi eğitim kurumundan ve öğretmenden beklentilerinin incelenmesi. Sinop Üniversitesi Sosyal Bilimler Dergisi, 3(2), 161-178.

Feeney, S.ve Moravick, E.(1987). A thing of beauty: Aesthetic development in young children. Young Children, September; 7-15.

Fetihi, L. (1998). Okul öncesi eğitimde yönetici-öğretmen ilişkisi. Yayımlanmamış doktora tezi, Marmara Üniversitesi, İstanbul.

Fidan, N. V. ve Erden, M.(1993). Eğitime Giriş. Ankara: Meteksan Matbaacılık.

Gordon, M ve Browne, K.W. (2007). Beginning Essentials İn Early Childhood Education: Canada.

Gökdemir, M. A. (2019). Problems encountered by preschool education teachers in art activities and solution offers (Mardin Sample). SDU International Journal Of Educational Studies, 6(2), 1-14.

Göle, M.O. ve Temel, Z.F. (2015). Okul öncesi öğretmenlerinin nitelikli bir okul öncesi eğitim programında bulunması gereken özelliklere ilişkin görüşlerinin incelenmesi. Mersin Üniversitesi Ĕ̆itim Fakültesi Dergisi, 11(3), 663-684.

Gülay Ögelman, H. ve Karakuzu, E. (2016). Meb 2013 okul öncesi eğitim programı'nda belirtilen öğrenme merkezlerinin uygulamaya yansımalarının incelenmesi: Aydın ili örneği. Krrıkkale Üniversitesi Sosyal Bilimler Dergisi, 6(2), 73-98.

Gülçiçek, T., Tonga, F.E. ve Tantekin Erden, F. (2019). Examining Turkish early childhood education curriculum in terms of mainstream curriculum models. OMÜ Eğitim Fakültesi Dergisi, 2019, 38(2), 77-106.

Güldalı, Ş. ve Demirbaş, İ. (2017). Okul öncesi eğitim programı ile ilkokul hayat bilgisi öğretim programının sarmallığının incelenmesi. Mersin Üniversitesi Eğitim Fakültesi Dergisi, 13(3), 1084-1105.

Gürsimsek, İ. (2003) Okuloncesi Eğitime Aile Katılımı Ve Psikososyal Gelisim. KUYEB, 3(1), 125-144.

Gürkan, T. (2013). Okul Öncesi Eğitim Program. R.Zembat(Ed.). Okul Öncesinde Özel Öğretim Yöntemleri. Ankara: Anı Yayıclık.

Gürkan, T. ve Koran, N. (2015). 36-72 Aylık Çocuklar İçin Okul Öncesi Eğitim Programının Çocuğun Katılım Hakkına Yer Verme Durumu Açısından İncelenmesi. Journal of Teacher Education and Educators, 3(2), 203-226.

Güzelyurt, T., Birge, F. ve Ökten, A. (2019). Okul öncesi öğretmenlerinin aile katılımına ilişkin görüşleri. Kocaeli Üniversitesi Eğitim Dergisi, 2(1), 64-74. 
Hacısalihoğlu Karadeniz, M. (2014). Okul öncesi öğretmenlerinin matematik eğitiminde teknolojiden yararlanma durumlarının belirlenmesi. Adıyaman University Journal of Educational Sciences, 2014, 4(2), 119-144.

Halstead, J. M. ve Taylor, J. M. (2000). Learning and teaching about values: A review of recent research. Cambridge Journal of Education, 30(2), 169-202.

Hamamcl, Z. ve Akyol, A.K. (2003). Çocuklarda empati gelişimi ve bilişsel gelişimin incelenmesi. kültürlerin buluşmass: Erken Çocukluk Gelişimi Ve Eğitime Yansımaları. OMEP Dünya Konsey Toplantısı ve Konferansı Bildiri Kitabı, Kuşadası/Türkiye.

Kale, M. (2010). Eğitimin temel kavramları. (Ed.). E. Karip, Eğitim Bilimine Giriş, Ankara: Pegem Akademi Yayımları.

Kandır, A. (1999). Okul Öncesi Eğitim Kurumlarnnda Etkinliklerin Planlanması. Gazi Üniversitesi Anaokulu-Anasınıfi Öğretmeni El Kitabı. İstanbul: Ya-Pa Yayım Pazarlama.

Kardeş, S. ve Güney Karaman N. (2018). Okul öncesi öğretmenlerinin çocuğun cinsel eğitimine ilişkin görüşleri. Abant İzzet Baysal Üniversitesi Eğitim Fakültesi Dergisi, 18(3), 1554-1570.

Kartal, H. ve Güner, F. (2016). Okul öncesi eğitim programı etkinlik kitabındaki etkinliklerin ses bilgisi farkındalığı açısından incelenmesi. Ana Dili Ĕğitimi Dergisi. 5(1), 14-30.

Kaya, Y., Günay, R. ve Aydın, H. (2016). Okul öncesi eğitimde drama yöntemi ile işlenen değerler eğitimi derslerinin farkındalık düzeyi üzerindeki etkisi. Sakarya University Journal of Education, 6(1), 23-37.

Kayhan, N. ve Kılıç, D. (2014). Türkiye ve bazı avrupa birliği ülkelerinde okul öncesi öğretmenliği programlarında fen eğitiminin incelenmesi. Çukurova Üniversitesi Eğitim Fakültesi Dergisi, 43(2), 83-102.

Kıldan, A. O. (2012). Okul öncesi eğitimin amacına yönelik öğretmen ve veli görüşleri. Kastamonu Ĕ̆itim Dergisi, 20(1), 135-150.

Koç Akran, S. ve Kocaman, İ. (2018). Öğretmenlerin ve velilerin okul öncesi eğitim kurumlarındaki veli toplantılarına ilişkin algıları. Uluslararası Eğitim Bilim ve Teknoloji Dergisi, 4(2), 97-110.

Koçyiğit, S. (2014). Çocukların Bakış Açısıyla Okul Öncesi Eğitim. Pamukkale Üniversitesi Ĕ̆itim Fakültesi Dergisi, Sayı 36, 203-214.

Kök, M., Koçyiğit, S., Tuğluk, M.N. ve Bay, E. (2008). Okul öncesi dönem çocuklannda görülen sorunların öğretmen görüşlerine göre değerlendirilmesi. Atatürk Üniversitesi Kazım Karabekir Eğitim Fakültesi Dergisi, 17, 82-93. 
Köksal, Ö., Balaban Dağal, A. ve Duman, A. (2016). Okul öncesi öğretmenlerinin okul öncesi eğitim programı hakkındaki görüşlerinin belirlenmesi. International Journal of Social Science, Sayl 46, 379-394.

Kutlu Abu, N. ve Kayar, Z. (2020). Okul öncesi öğretmenlerinin aile katılımma yönelik görüşlerinin derinlemesine incelenmesi. Mehmet Akif Ersoy Üniversitesi Eğitim Fakültesi Dergisi, 54, 156-183.

Kuzgun, H. ve Özdinç, F. (2017). Okul öncesi eğitimde teknoloji kullanımına yönelik öğretmen görüşlerinin incelenmesi. Uşak Üniversitesi Sosyal Bilimler Dergisi, 10(-ERTE Özel Saylsl), 83-102.

Küçükturan, A. G. ve Altun A., Akbaba-Altun, S. (2013). Türkiye'de okul öncesi eğitimin geliştirilmesine yönelik uygulamalar. The Journal of Academic Social Studies. 6(7). 783-801.

Livatyall, H. (2011). Okul ve okulda zaman yönetimi. (Edt. Gürsel M.), Konya: Eğitim Akademi.

Manolova Yalçı, O., Durmuşoğlu Saltalı, N. ve Ateş, M. A. (2020). Okul öncesi eğitimde aranan veli profili. Uluslararası Sosyal Bilimler ve Eğitim Dergisi USBED, 2(2), 1-23.

MEB. (2013). Okulöncesi eğitim programı, Ankara: MEB.

Miles, M. B. ve Huberman, A. M. (1994). Qualitative data analysis. (2nd ed.). Thousand.

Miller, E. (2005). Fighting technology for toddlers. Education Digest: Essential Readings Condensed For Quick Review, 71(3), 55-58.

Milli Eğitim Bakanlığı, (2018). Strateji geliştirme başkanlığı. Ankara: MEB Yayımları.

Morrison, G. (2012). Early childhood education today. Boston: Pearson.

Muşlu Kaygisız, G. (2020). Fen bilimleri dersi öğretim programı ve okul öncesi eğitim programındaki kazanımların çevre eğitimi açısından incelenmesi. Uluslararası Erken Çocukluk Ĕ̆itimi Çalışmaları Dergisi, 5(1), $29-47$.

NAEYC \& NAECS/SDE (National Association for the Education of Young Children \& National Association of Early Childhood Specialists in State Departments of Education) (2003). Early childhood curriculum, assessments and program evaluation: Building an affective, accountable system in programs for children birth through age 8, 1- 30.

Oğuzkan, Ş. ve Oral, G. (1997). Okulöncesi eğitimi. İstanbul: Milli Eğitim Basımevi.

Ok, S. (2016). Öğretmen ve ailelere göre okul öncesi eğitimde okul-aile işbirliğinin önemi. İstanbul Aydın Üniversitesi Dergisi, 32, 61-79. 
Okutan, N. (2003). Erken çocukluk eŏitimi politikaları: Yayğınlaşma, yönetişim ve yapılar toplantısı raporu. Ankara: M.E.B., AÇEV, UNICEF ve Eğitim Reformu Girişimi.

Oktay, A. (2000). Yaşamın sihirli yılları (İkinci Baskı). İstanbul: Epsilon.

Öktem, T. (1986). S.S.Y.B. sosyal hizmetler ve çocuk esirgeme kurumu genel müdürlüğ̈̈ kuruluşlarında okulöncesi eğitimi ve yaygınlaşması çalışmaları. 4. Ya-Pa Okulöncesi Eğitimi ve Yaygınlaştırma Semineri. Ankara: Ya-Pa Yayımları.

Önal N. ve Keleş O. (2012). Teachers' views regarding the use of technological materials in pre-school educational institutions. Mediterranean Journal of Educational Research, 14a, 820-824.

Özenç, M. (2020). Okul öncesi eğitimi programındaki kazanımlar ile ilkokul 1. sınıf kazanımları ne kadar uyumlu?. Eğitim ve Insani Bilimler Dergisi, 11(21), 97 110.

Özkubat, S. (2013). Okul öncesi kurumlarında eğitim ortamlarının düzenlenmesi ve donanım. Adnan Menderes Üniversitesi Eğitim Fakültesi Eğitim Bilimleri Dergisi, 4(2), 58-66.

Özsırkıntı, D., Akay, C. ve Yılmaz Bolat, E. (2014). Okul öncesi öğretmenlerinin okul öncesi eğitim programı hakkındaki görüşleri: Adana İli örneği. Ahi Evran Üniversitesi Kırşehir Eğitim Fakültesi Dergisi (KEFAD), 15(1), 313-331.

Özyürek, A., Özkan, İ., Begde, Z. ve Yavuz, N.F. (2015). Okul öncesi dönem çocuklar için hareket ve sosyal becerilerin gelişiminin desteklenmesine yönelik eğitim programı. Uluslararası Bilim Kültür ve Spor Dergisi, 3(11), 323340.

Pehlivan, D.(2006). Okul öncesi eğitim alan ve almayan öğrencilerin ilkokuma yazmaya geçiş sürecinin, öğretmen ve öğrenci görüşleri doğrultusunda değerlendirilmesi. Çukurova Üniversitesi Sosyal Bilimler Enstitüsü İlköğretim Anabilim Dalı. Yüksek Lisans Tezi.

Poyraz, H. (2003). Okul öncesi eğitimin ilke ve yöntemleri. Ankara: Anı Yayımcılık.

Sabancı, A. Altun, M. ve Uçar Altun, S. (2018). Okul yöneticilerinin, öğretmenlerin ve velilerin görüşlerine göre ana sınıfı eğitiminde karşılaşılan sorunlar. $\mathrm{Ku}$ ram ve Uygulamada Ĕ̆itimi Yönetimi Dergisi, 24(2), 339-385.

Saklan, E. ve Erginer, A. (2016). Türkiye'de okul öncesi eğitime ilişkin politika ve finansman uygulamaları. Neoşehir Hacı Bektaş Veli Üniversitesi Sosyal Bilimler Enstitüsü Dergisi, 6(2), 15-44.

Sapsağlam, Ö. (2013). Değerlendirme boyutuyla okul öncesi eğitim programları(1952-2013). Uluslararası Türk Eğitim Bilimleri Dergisi, 1, 63-73. 
Sapsağlam, Ö. (2020). Okul öncesi eğitim programlarının milli kavramlar açısından incelenmesi. Türkiye Ë̆itim Dergisi, 5(1), 1-17.

Senemoğlu, N. (1994). Okulöncesi eğitim programı hangi yeterlikleri kazandırmalıdır? Hacettepe Üniversitesi Eğitim Fakültesi Dergisi, 10(10), 21-30.

Shenton, A. K. (2004). Strategies for ensuring trustworthiness in qualitative research Project. Education for information, 22(2), 63-75.

Taner, M. ve Başal, H.A (2005). Farklı sosyoekonomik düzeylerde okulöncesi eğitimi alan ve almayan ilköğretim birinci sınıf öğrencilerinin dil gelişimlerinin cinsiyete göre karşılaştırılması. Uludă̆ Üniversitesi Eğitim Fakültesi Dergisi, 18(2), 395-420.

Tantekin Erden, F. ve Altun, D. (2014). Sınıf öğretmenlerinin okul öncesi eğitim ve ilköğretime geçiş süreci hakkındaki görüşlerinin incelenmesi. Ilköğretim Online, 13(2), 481-502.

Temel, Z. F., Kandır, A., Erdemir, N., ve Koçer-Çiftçibaşı, H., (2005), Okul öncesi eğitimde proje yaklaşımı ve program örnekleri. İstanbul: Morpa Kültür Yayımları.

Tok, E. (2002). Okul öncesi eğitim kurumlarnnda yönetim sorunları. Yayımlanmamış yüksek lisans tezi. Pamukkale Üniversitesi Sosyal Bilimler Enstitüsü, Denizli.

Torun Yeterge, H., Yıldız Demirtaş, V., Coşkun, U. H., Vardarcı Kaçar, G. (2020). Aktif öğrenme yaklaşımına dayalı hazırlanan okul öncesi eğitim programının çocukların sosyal yetkinlik düzeylerine etkisi. Trakya Ĕ̆itim Dergisi, 10(2), 429-443.

Tuğrul, B. (2006). Okul öncesi dönemde düşünme becerilerinin gelişmesinde yaratıı bir süreç olarak drama. Yaratıcı Drama Dergisi, 1(2), 1343-1381.

Tuncer, B. (2015). Okul öncesi eğitimdeki çağdaş yaklaşımların incelenmesi ve meb okul öncesi programıla karşılaştırılması. Ylldız Teknik Üniversitesi, Sosyal Bilimler Enstitüsü, Ĕ̈̆itim Bilimleri, 1(2), 39-58.

Turaşlı, N. (2007). Okulöncesi eğitime giriş, Ankara: Anı Yayımclık.

Ulu, H., ve Baş, Ö. (2020). Öğretmen adaylarının sosyal ağ sitelerini kullanım amaçları, eleştirel düşünme eğilimleri ve medya okuryazarlıkları arasındaki ilişkiler. Hacettepe Üniversitesi Ĕ̆itim Fakültesi Dergisi, 35(3), 556-574.

United Nations Educational, Scientific and Cultural organization (UNESCO), (1994). The salamanca statement and framework for action on special needs education. Paris. 
Unutkan, Ö.P. (2007). Okul öncesi dönem çocuklarının matematik becerileri açısından ilköğretime hazır bulunuşluğunun incelenmesi. Hacettepe Üniversitesi Eğitim Fakültesi Dergisi, 32, 243-254.

Usta, E. ve Korkmaz, Ö. (2010). Öğretmen adaylarının bilgisayar yeterlikleri ve teknoloji kullanımına ilişkin algıları ile öğretmenlik mesleğine yönelik tutumları. Uluslararası Insan Bilimleri Dergisi. 7(1). 1335-1349.

Uyanık Balat, G. (2011). Fen nedir ve çocuklar feni nasıl öğrenir? (Ed.) B. Akman, Gülden Uyanık Balat, Tülin Güler. Okul Öncesi Dönemde Fen Eğitimi. Ankara: PegemA.

Uyanık, Ö ve Kandır, A.(2010). Okul öncesi dönemde erken akademik beceriler. Kuramsal Ĕ̆itimbilim Dergisi, 3(2), 118-134.

Uysal, A. ve Balkan, İ.K. (2015). Sosyal beceri eğitimi alan ve almayan okul öncesi çocukların, sosyal beceri ve benlik kavramı düzeyleri açısından karşılaştırılması. Psikolojik Çalışmaları, 35(1), 27-56.

Ünal, F. (2013). Aile eğitiminde ebeveyn hakları ile ilgili yasalar ve etik kurallar. F. Temel (Ed.), Aile Ĕ̆itimi ve Erken Çocukluk Eğitiminde Aile Katılım Çalısmaları. Ankara: Anı Yayımclik.

Vogel, N. (2012). Arranging the active learning environment: Setting Up The Preschool Classroom. Resource. 11-14.

Yalçın, V. ve Uzun, H. (2018). Okul öncesi öğretmenlerinin öğretim yöntem ve teknikleri kullanma düzeylerinin bazı değişkenlere göre incelenmesi (Kilis ve Gaziantep İli Örneği). Uluslararası Erken Çocukluk Eğitimi Çalışmaları Dergisi, 3(2), 42-54.

Yıldız Demirtaş, V. (2015). Aktif öğrenme ve işbirlikli öğrenme yöntem ve teknikleri. İçinde B. Doğan ve V. Alkan (Eds.) Öğretim Ilke ve Yöntemleri. 245-288. Ankara: Eğiten Kitap.

Yllmaz, N. (2003). Türkiye'de okulöncesi eğitimi erken çocuklukta gelişim ve eğitimde yeni yaklaşımlar. İstanbul: Morpa Kültür Yayımları.

Yiğit, C., Özyurt, M., ve Adıyaman, H. (2019). Okul öncesi öğrencilerinin programın kazanımlarına ulaşma durumlarının değerlendirilmesine ilişkin bir model önerisi. Eğitimde Kuram ve Uygulama, 15(3), 237-252.

Zembat, R. (2007). Okul öncesi eğitimde nitelik. Okul öncesi eğitimde güncel konular. İstanbul: Morpa Yayımları, 25-44.

Zembat, R. (2012). Okul öncesi öğretmenlerinin okul yöneticisi, meslektaşları ve aileler bağlamında algıladıkları çatışma durumlarının incelenmesi. Eğitim ve Bilim,37,163. 
Zembat, R., Günşen, G. ve Gök Çolak, F. (2019). Okul öncesi öğretmenlerinin erken çocukluk eğitiminde uygulanan farklı yaklaşımlar hakkındaki bilişsel haritaları. Trakya Üniversitesi Sosyal Bilimler Dergisi, 21, 1-19.

Zembat, R., ve Unutkan Polat, Ö. (2001). Okul öncesi dönemde çocuğun sosyalleşmesinde ailenin yeri. İstanbul: Ya-Pa Yayımları.

\section{Kaynakça Bilgisi / Citation Information}

Yerliyurt, N. S. ve Ersoy, M. (2021). Okul öncesi eğitim programı ile ilgili dergipark'ta yayimlanan makalelerin incelenmesi: 2013-2020. OPUS-Uluslararası Toplum Araştırmaları Dergisi, 17(37), 4104-4153. DOI: 10.26466/opus. 866620 